This manuscript, entitled Early evolution of the Adelaide Superbasin, is a preprint that has not undergone peer-review. It has been submitted to Geosciences but is yet to undergo peer-review and be formally accepted for publication. Subsequent versions of this manuscript may have slightly different content. If accepted, the final version of this manuscript will be available via the "published version" link at the top of this webpage. Please feel free to contact the main author; we welcome feedback and queries

Jarred C. Lloyd ${ }^{1,2}$; Alan S. Collins ${ }^{1}$; Morgan L. Blades ${ }^{1}$; Sarah E. Gilbert ${ }^{3}$; Kathryn J. Amos ${ }^{2}$

1. Tectonics and Earth Systems Group, and Mineral Exploration CRC, Department of Earth Sciences, University of Adelaide, Adelaide, SA 5005, Australia

2. Australian School of Petroleum and Energy Resources, University of Adelaide, Adelaide, SA 5005, Australia

3. Adelaide Microscopy, University of Adelaide, Adelaide, SA 5005, Australia

Corresponding author email: jarred.lloyd@adelaide.edu.au 


\section{Early evolution of the Adelaide Superbasin}

Jarred C. Lloyd ${ }^{1,2}$; Alan S. Collins ${ }^{1}$; Morgan L. Blades ${ }^{1}$; Sarah E. Gilbert ${ }^{3}$; Kathryn J. Amos²

1. Tectonics and Earth Systems Group, and Mineral Exploration CRC, Department of Earth Sciences, University of Adelaide, Adelaide, SA 5005, Australia

2. Australian School of Petroleum and Energy Resources, University of Adelaide, Adelaide, SA 5005, Australia

3. Adelaide Microscopy, University of Adelaide, Adelaide, SA 5005, Australia

\section{Abstract}

Continental rifts have a significant role in supercontinent breakup, and the development of sedimentary basins. The Australian Adelaide Superbasin is one of the largest and best-preserved rift systems that initiated during the breakup of Rodinia, yet substantial challenges still hinder our understanding of its early evolution and place within the Rodinian supercontinent. In the past decade, our understanding of rift and passive margin development, mantle plumes and their role in tectonics, geodynamics of supercontinent breakup, and sequence stratigraphy in tectonic settings has advanced significantly, however literature on the early evolution of the Adelaide Superbasin has not been updated to reflect these advancements. Using new detrital zircon age data for provenance, combined with existing literature, we examine the earliest tectonic evolution of the Adelaide Superbasin in the context of our modern understanding of rift system development. A new maximum depositional age of $893 \pm 9$ Ma from the lowermost stratigraphic unit provides a revised limit on the initiation of sedimentation and rifting within the basin. Our model suggests that the basin evolved through an initial pulse of extension exploiting pre-existing crustal weakness to form half-grabens. Tectonic quiescence and stable subsidence followed, with deposition of a sourceward-shifting facies tract. Emplacement and extrusion of the Willouran Large Igneous Province occurred at c. $830 \mathrm{Ma}$ initiating a new phase of rifting. This rift renewal led to widespread extension and subsidence with deposition of the Curdimurka Subgroup, which constitutes the main cyclic rift sequence in the Adelaide Superbasin. Our model suggests that the Adelaide Superbasin formed through rift propagation an apparent triple junction, rather than apical extension outwards from this point. Additionally, we provide evidence suggesting a late Mesoproterozoic zircon source to the east of the basin, and show that the lowermost stratigraphy of the Centralian Superbasin, which is thought to be deposited coevally, had different primary detrital sources.

\section{Introduction}

The breakup of the supercontinent Rodinia, and subsequent formation of Gondwana, coincided with critical Earth system changes that led to the Phanerozoic world of extensive macroscopic mineralised life, significantly oxygenated atmosphere and hydrosphere, and a buffered climate devoid of wholeplanet glaciations (Halverson et al. 2009; Shields et al. 2021; Tostevin \& Mills 2020). Determining any interdependence between these phenomena (e.g., Alcott et al. 2020; Gernon et al. 2016; Halverson et al. 2009; Mills et al. 2019) requires constructing full-plate tectonic reconstructions of the globe (Merdith et al. 2021; Merdith et al. 2017b) that themselves need a fundamental 
understanding of the temporal link between tectonically controlled geological features (such as rift basins) and plate tectonic phenomena (such as continental plate sundering and ocean crust formation; Collins et al. 2021; Merdith et al. 2017b).

The Adelaide Superbasin (Lloyd et al. 2020) is one of the largest and best preserved rift to passivemargin successions to form during the Neoproterozoic breakup of Rodinia, which included large continental rifts between the Australia, Amazonia, Baltica, Kalahari, Laurentia, and Siberia cratons (Bogdanova et al. 2009; Cawood et al. 2016; Li et al. 2008). The Adelaide Superbasin is thought to have formed the conjugate margin to western Laurentia in Rodinia (Brookfield 1993; Dalziel 1997; Hoffman 1991; Karlstrom et al. 1999; Merdith et al. 2017b; Moores 1991; Wingate et al. 2002), although other configurations for Rodinia have been suggested (e.g., Li et al. 2008; Li et al. 1995; Wen et al. 2017; Wen et al. 2018). Poor chronological control, sparse and ambiguous palaeomagnetic constraints, and a lack of young detrital zircon in the lower units of the Adelaide Superbasin have long hindered the research and testing of these Rodinia reconstructions. Research on the tectonic evolution of the Adelaide Superbasin has seen the geosyncline theory (Sprigg 1952), transition to plate tectonics (Preiss 1987; 2000), and a few targeted (Counts 2016; Job 2011; Mackay 2011) or more generalised (Keeman et al. 2020; Lloyd et al. 2020) studies since.

This research presents new detrital zircon $\mathrm{U}-\mathrm{Pb}$ and trace element data for the lowermost units of the Adelaide Rift Complex within the Adelaide Superbasin. We use these data, alongside existing literature to provide a refined, early tectonic evolution of the rift system during the deposition of the Callanna Group.

\section{Geological Background}

\subsection{Adelaide Superbasin}

The Adelaide Superbasin (Lloyd et al. 2020) is a large, Neoproterozoic to middle Cambrian sedimentary system at the southeast margin of Proterozoic Australia, which formed as a result of the breakup of the supercontinent Rodinia. The Adelaide Superbasin consists of several named basins and sub-basins that span the Neoproterozoic to early Cambrian. The largest and oldest of these is the Adelaide Rift Complex that is contiguous with the relatively undeformed rocks of the Torrens Hinge Zone, Stuart Shelf (Sprigg 1952), and Coombalarnie Platform (Callen 1990). Two Cambrian basins, the Arrowie Basin, and the Stansbury Basin, are also considered as part of the Adelaide Superbasin (Lloyd et al. 2020; Preiss et al. 2002) [Figure 1]. Whilst present day exposure of the sedimentary basin is approximately $600 \mathrm{~km}$ north to south, the basin spans over 1,100 km from central Australia through to Kangaroo Island. Deposition within the Adelaide Superbasin spans over 300 million years of Earth's history and stretches from the northernmost regions of South Australia, narrowing in the South Mount Lofty Ranges at the Fleurieu Peninsula and extending onto Kangaroo Island. Further south, links with coeval sequences in Antarctica and eastern Tasmania are unclear, but possible (Mulder et al. 2018). The basin began as an intracontinental rift system that successfully progressed to a passive margin basin in its southeast region, yet remained a failed rift in the north. Deposition 
within the basin ceased during the Delamerian orogeny c. 514-490 Ma (Drexel \& Preiss 1995; Foden et al. 2006; Foden et al. 2020; Preiss 2000). The stratigraphy of the Adelaide Superbasin is divided into three supergroups (Preiss 2000), two for the Neoproterozoic sequences and the third for the Cambrian sequences, with numerous group and subgroup level divisions. In the Neoproterozoic, the Warrina Supergroup is comprised of the Callanna, Burra, and Poolamacca Groups, and the Heysen Supergroup contains the Umberatana, Wilpena, Torrowangee, and Farnell Groups. Each of these groups are further divided into numerous subgroups (see Lloyd et al. 2020). Here we focus on the Callanna Group, which is best preserved in the failed arm of the rift system. The reader is referred to Preiss (1987), Preiss (2000), Counts (2017), Lloyd et al. (2020), Cowley (2020) and references therein for further detail on the geological history of the Adelaide Superbasin.

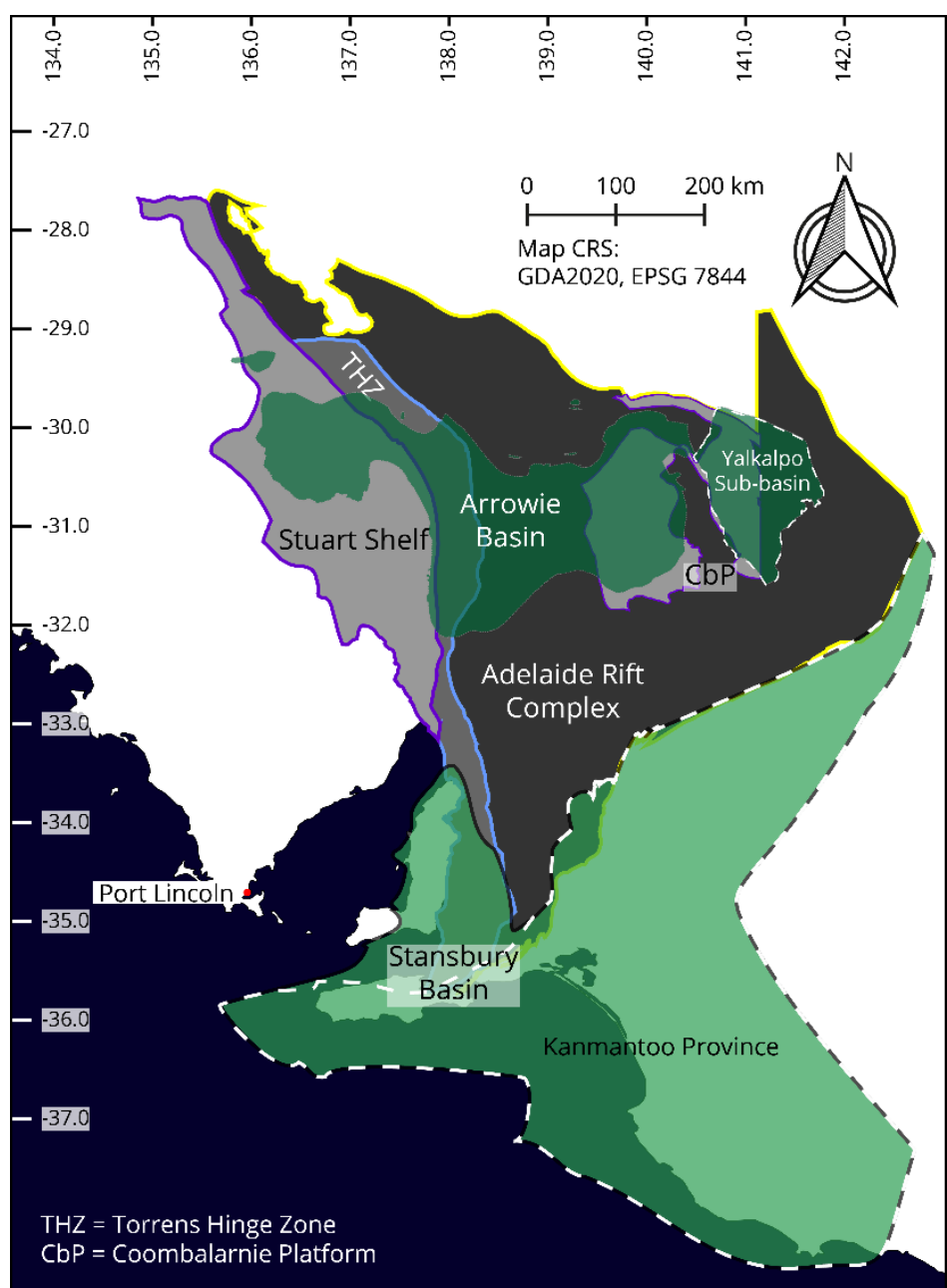

Figure 1 - Map of known Adelaide Superbasin extent and basin subdivisions (derived from Lloyd et al. 2020).

\subsubsection{Callanna Group}

The oldest stratigraphy of the Adelaide Superbasin is represented by the Callanna Group (Forbes et al. 1981), which is further subdivided into the Arkaroola Subgroup (Forbes et al. 1981; Mawson 1949; Thomson 1966), and the Curdimurka Subgroup (Forbes et al. 1981), that is inferred to be the younger of the two (Preiss 1993). For historical reference, the now outdated "Willouran Series" is equivalent to the Callanna Group, although this has not always been the case (Preiss 1987). In New South Wales, the Poolamacca Group (Cooper \& Tuckwell 1971) is thought to be the equivalent of the Arkaroola Subgroup (Preiss 1987). The known depositional extent of the Callanna Group [Figure 2] is restricted to the eastern (NSW), central, and northern Adelaide Rift Complex (including the Davenport and Denison Ranges), Stuart Shelf, and possibly the eastern Officer Basin. 


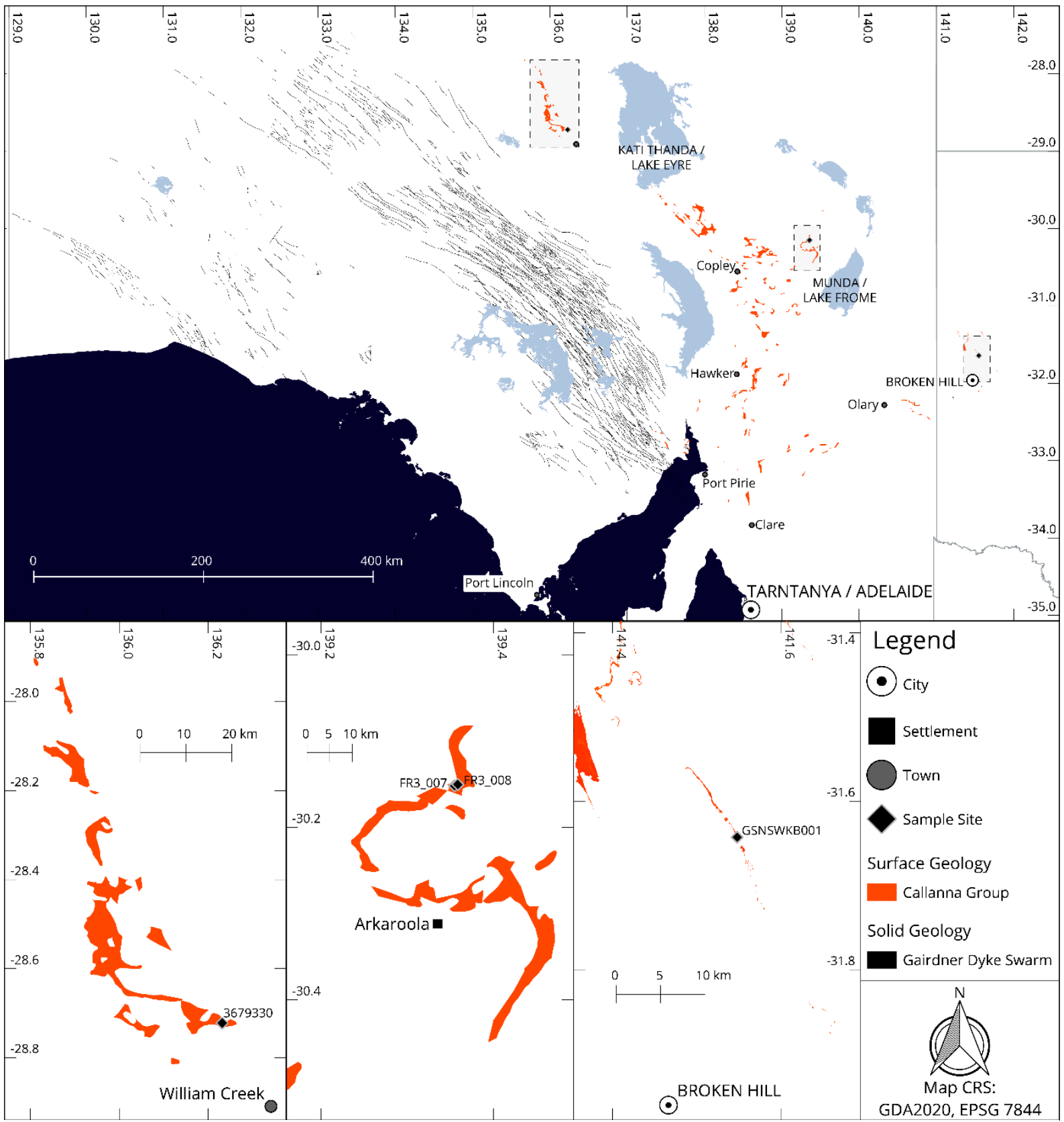

Figure 2 - Distribution of the exposed Callanna Group rocks (orange), the subsurface distribution of the Gairdner Dolerite (black lines), and insets showing sample locations (west to east).

The Callanna Group is characterised by initially siliciclastic sedimentation transitioning to carbonate and evaporite dominated deposition, with minor, interbedded, mafic to intermediate volcanic and volcanogenic sequences. The Arkaroola Subgroup [Figure 3, Supplementary Figure S1] comprises of basal siliciclastic units (e.g., Younghusband Conglomerate, Paralana Quartzite), overlain by a (meta)carbonate unit (e.g., Wywyana Formation) and finally capped by mafic (meta-)igneous rocks (e.g., Wooltana Volcanics). The basal siliciclastic and middle carbonate sequences are thought to be deposited in sag basins from the gradual subsidence of a stable craton, prior to rifting (Preiss 2000), or alternately deposition as syn-rift sediments penecontemporaneous with faulting (Coats \& Blissett 1971). The igneous sequences at the top of the Arkaroola Subgroup are almost exclusively metabasaltic rocks with minor interbedded sediments (Hillyard 1990; Preiss 1987). These igneous sequences are inferred to have been extruded in subaerial settings (Hillyard 1990) as continental 
125 tholeiitic (flood) basalts (Crawford \& Hillyard 1990; Hillyard 1990; Powell 1998; Preiss 1987; 2000;

126 Wade, CE et al. 2014). The Wooltana Volcanics and its equivalent units of the uppermost Arkaroola

127 Subgroup are the most voluminous igneous rocks recognised in the Adelaide Superbasin and have

128 been termed the Willouran Large Igneous Province (LIP); alternately, Willouran Basic Province or

129 Gairdner LIP (Crawford \& Hillyard 1990; Hillyard 1990; Huang et al. 2015; Wade, CE et al. 2014;

130 Wang, X-C et al. 2010; Werner et al. 2018; Wingate et al. 1998). Neoproterozoic mafic volcanics of

131 the Coompana Province, c. 860 Ma may also be part of the Willouran LIP (Travers 2015). The

132 Willouran LIP [Figure 2] is interpreted to represent the first major phase of rifting within the Adelaide

133 Superbasin, and thus initiation of Rodinia break-up at the eastern margin of Proterozoic Australia that

134 led to development of the palaeo-Pacific Ocean (Merdith et al. 2017b). At present day, the only

135 exposures of complete sections of the Arkaroola Subgroup [Figure 3] are located in the

136 Arkaroola/Mount Painter area, and the Davenport and Denison Ranges (Peake and Denison Inliers)

137 [Supplementary Figure S1]. Isolated blocks of Arkaroola Subgroup are recognised in carbonate

138 megabreccia (diapirs) throughout the Adelaide Superbasin, but particularly within the Willouran

139 Ranges. The equivalent Poolamacca Group crops out in the Barrier Ranges of New South Wales

140 [Figure 1]. 
141 The Curdimurka Subgroup is thought to

142 overlie the Arkaroola Subgroup and locally

143 exceeds $8 \mathrm{~km}$ stratigraphic thickness. As

144 a result of tectonic, and salt tectonic

145 dismemberment, no wholly intact section

146 through the Curdimurka Subgroup has

147 been identified (Ambrose et al. 1981;

148 Forbes et al. 1981; Hearon IV et al. 2015;

149 Mackay 2011; Preiss 1985; 1987; 2000).

150 However, composite sections have been

151 developed for the Willouran Ranges

152 (Forbes et al. 1981) [Figure 3], the

153 Davenport and Denison Ranges (Ambrose

154 et al. 1981), the Worumba Anticline

155 (Preiss 1985), and the Spalding Inlier

156 (Preiss 1974). The most intact of these

157 composite sections is within the Willouran

158 Ranges [Supplementary Figure S1]. The

159 Curdimurka Subgroup is comprised of a

160 cyclical sequence of evaporitic mixed

161 carbonate, and siliciclastic rocks, with

162 minor intermediate to felsic igneous rocks

163 (Ambrose et al. 1981; Fabris et al. 2005;

164 Mackay 2011; Preiss 1987; 2000;

165 Stüeken et al. 2019). The carbonate

166 sequences comprise of stromatolitic

167 limestones and dolostones, and cryptalgal

168 dolostone with abundant evaporite

169 mineral pseudomorphs and locally, tepee

170 structures. The siliciclastic sequences

171 include laminated, pyritic, and

172 carbonaceous siltstone, and sandstones

173 and siltstones with occasional graded

174 bedding, halite casts and load casts.

175 Additionally, feldspathic, and carbonate-

176 cemented, cross-bedded sandstone, with

177 occasional heavy mineral laminations and

178 halite casts are present. The stratigraphic

179 names of the Callanna Group, general

180 geographic locations, and approximate

181 relative stratigraphic positions are

182 outlined in Supplementary Figure S1.

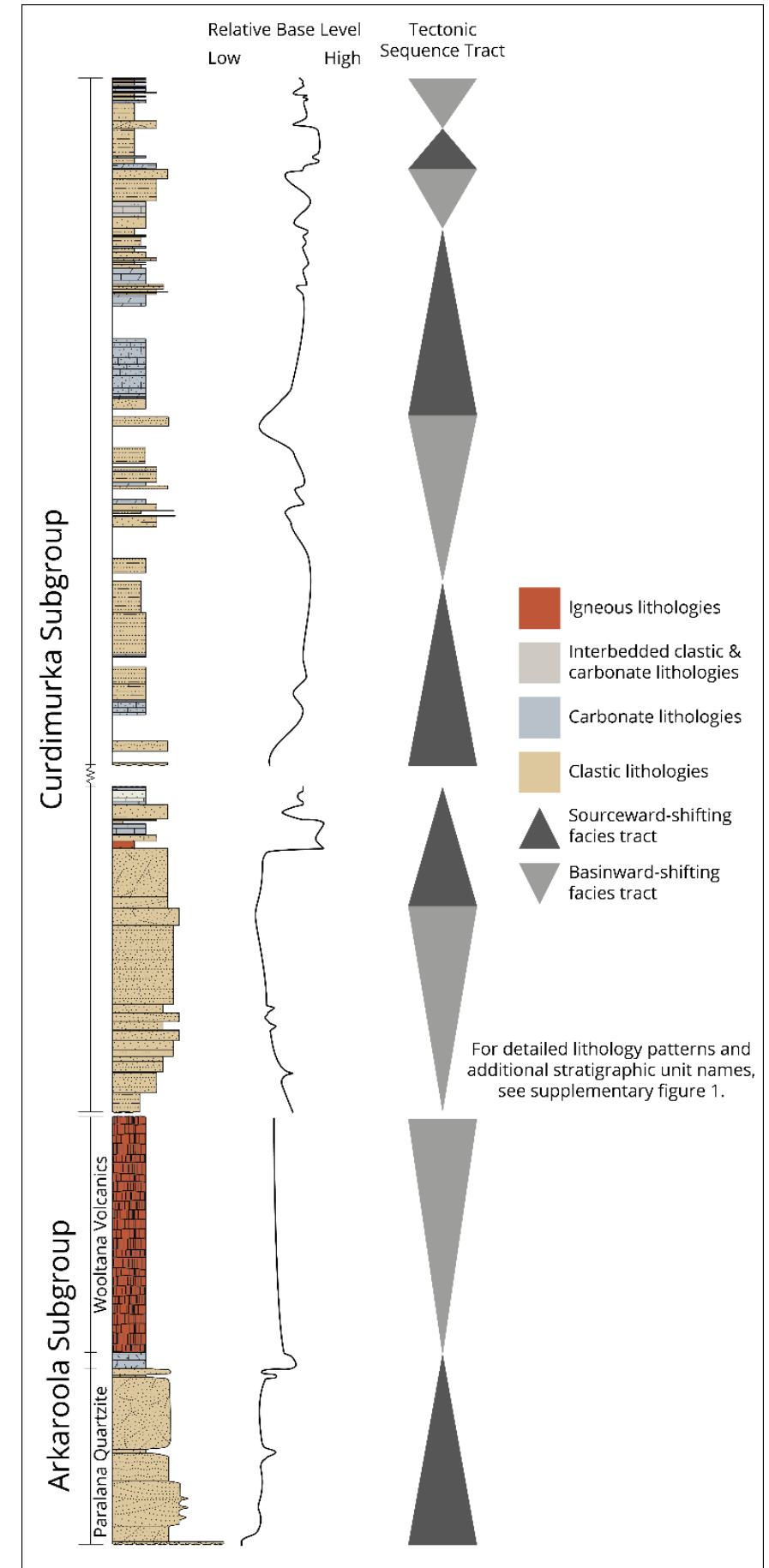

Figure 3 - Simplified (composite) stratigraphic log of the Callanna Group based on the type sections from Arkaroola and the Willouran Ranges. Relative base level utilises further information from Mackay (2011) and Preiss (1987; 2000). Tectonic successions follow terminology of Matenco and Haq (2020) sourceward-shifting facies tracts are where accommodation space is created faster than the rate of sediment supply $(\delta \mathrm{AS} / \mathrm{SS}=>1$ ) and basinward-shifting facies tracts are where the rate of sediment supply outdoes the creation of accommodation space $(\delta \mathrm{AS} / \mathrm{SS}=<1)$. 


\section{Methods}

184 Three samples were analysed for detrital zircon geochronology, two from the Paralana Quartzite

185

186

187

188

189

190

191

192

193

194

195

196

197

198

199

200

201

202

203

204

205

206

207

208

209

210

211

212

213

214

215

216

217

218

219

220

221

222

223

224 (FR3_007, FR3_008), and one from the Lady Don Quartzite in the eastern part of the superbasin (GSNSWKB001; see Figure 2). A fourth volcano-sedimentary sample, 3679330, was also analysed in the hope of obtaining an indication of the crystallisation age of the Cadlareena Volcanics-a presumed equivalent of the Wooltana Volcanics (Ambrose et al. 1981; Figure 3). These samples were selected to investigate the provenance earliest sedimentary rocks of the Adelaide Superbasin, and any spatially related variations in coeval sequences.

Rock samples were first prepared for detrital zircon analysis by crushing the rock samples using a jaw crusher, disk mill, then sieved using nylon mesh of $79 \mu \mathrm{m}$ and $400 \mu \mathrm{m}$. All equipment was thoroughly cleaned by vacuuming, ethanol, and compressed air between each sample. New sieve mesh was used for each sample. Mineral separation was completed by water panning of the 79-400 $\mu \mathrm{m}$ fraction and use of LST heavy liquid set to a density of $2.85 \pm 0.02 \mathrm{gcm}^{-3}$. Zircon was then handpicked and mounted in an epoxy resin. Any grain that remotely resembled a zircon was picked to minimise human bias, an issue highlighted by Slama and Košler (2012) and Dröllner et al. (2021). Where permitted by zircon yields, at least 300 zircons were picked per sample, otherwise all zircons in the sample were picked. The mounts were then imaged via cathodoluminescence on either a FEI Quanta 600 scanning electron microscope (for zircon analysed in 2020) or a Cameca SXFive Electron Microprobe (for zircon analysed in 2021). The zircons were then analysed using Laser Ablation Inductively Coupled Plasma Mass Spectrometry (LA-ICP-MS) to obtain a suite of elemental data for $\mathrm{U}-\mathrm{Pb}$ geochronology and rare earth element (REE) analysis. All zircons were analysed using a Resonetics M-50 (193 nm ArF excimer) laser ablation system coupled with an Agilent 7900x inductively coupled plasma mass spectrometer. All analytical instruments used are housed at Adelaide Microscopy, University of Adelaide, Australia.

Four standards were used during analysis, GEMOC GJ-1 (Horstwood et al. 2016; Jackson et al. 2004), Plešovice (Horstwood et al. 2016; Sláma et al. 2008), 91500 (Horstwood et al. 2016; Wiedenbeck, M. et al. 1995; Wiedenbeck, Michael et al. 2004), and the NIST610 glass (Jochum et al. 2011). Unknowns were bracketed by two analyses of GJ-1, followed by a combined two to three analyses of Plešovice and 91500, and two analyses of NIST610 every 20-30 unknowns. GJ-1 was used as the primary calibration standard for $\mathrm{U}-\mathrm{Pb}$ ratios and NIST610 was used as the primary calibration standard for $\mathrm{Pb}$ isotope ratios and trace element data. ${ }^{91} \mathrm{Zr}$ was used as the internal standard for trace element data with a value of $431,400 \mathrm{ppm}(43.14 \mathrm{wt} \%)^{91} \mathrm{Zr}$ assigned to unknowns. Plešovice and 91500 were used as validation standards. A 30 second gas blank followed by either a 40 second or 30 second ablation (session on 2021-03-30) time was used with a laser repetition rate of $5 \mathrm{~Hz}$. A spot size of $29 \mu \mathrm{m}$ and a nominal fluence of $2 \mathrm{Jcm}^{-2}$ was used for zircon, and a spot size of $43 \mu \mathrm{m}$ using a nominal fluence of $3.5 \mathrm{Jcm}^{-2}$ was used for NIST610. Data were processed using LADR (Norris \& Danyushevsky 2018), version 1.1 .06 and output as "Full Analytical Uncertainty". No common Pb corrections were applied to the data. Reference material ratios for GJ1, Plešovice, and 91500 were set to the Chemical Abrasion Isotope Dilution Thermal Ionisation Mass Spectrometry (CA-ID-TIMS) values (uncorrected for thorium disequilibria and common- $\mathrm{Pb}$ ) of Horstwood et al. (2016). Weighted averages and dispersion statistics for all standards are available from the link in data availability. 
Statistical analysis of the zircon U-Pb data follows the method of Lloyd et al. (2020). Data are considered concordant if within $\pm 10 \%$, and a "meaningful" age if the $2 \sigma$ uncertainty is $\leq 10 \%$-if a datum satisfies both parameters it is termed a Filtered Age. Maximum depositional ages are determined from a stricter $2 \%$ concordance filter and use the older age of the three isotope ratios $\left.{ }^{207} \mathrm{~Pb} /{ }^{235} \mathrm{U},{ }^{206} \mathrm{~Pb} /{ }^{238} \mathrm{U},{ }^{207} \mathrm{~Pb} /{ }^{206} \mathrm{~Pb}\right)$ for a conservative estimate of the youngest single concordant grain. All ages are quoted with $2 \sigma$ uncertainty. Kernel density estimates (KDEs), and multidimensional scaling plots (MDS) were generated using IsoplotR (Vermeesch 2018). Key zircon trace element data are presented graphically using methods following Verdel et al. (2021) and additionally lanthanoid data are represented using violin plots and lambda representation (Anenburg 2020; O'Neill 2016).

234 Metadata for the LA-ICP-MS sessions,

235 data for all analyses,

236 cathodoluminescence images, and $\mathrm{R}$

237 code used to generate plots are

238 available from the links in data and code 239 availability.

\section{Results}

241 A total of 161 analyses were conducted

242 for sample FR3_008. Of these, 141

243 analyses passed filtering parameters,

244 with ages ranging from $2914 \pm 46 \mathrm{Ma}$ to

$245892 \pm 13 \mathrm{Ma}$ [Figure 4]. The primary

246 population peak of this sample is $\mathrm{c}$.

$2471550 \mathrm{Ma}$, with a secondary peak at $\mathrm{C}$.

$2481750 \mathrm{Ma}$, and tertiary peaks c. $1180 \mathrm{Ma}$

249 and $935 \mathrm{Ma}$. Four analyses lie outside

250 these populations, ranging from $2914 \pm$

25146 Ma to $2237 \pm 57$ Ma.

252 A total of 125 analyses were conducted

253 for sample FR3_007. Of these, 99

254 analyses passed filtering parameters,

255 with ages ranging from $3090 \pm 31$ Ma to

$2561305 \pm 17 \mathrm{Ma}$ [Figure 4]. The primary

257 population peak of this sample is $\mathrm{c}$.

$2581680 \mathrm{Ma}$, with secondary population

259 peaks c. $2480 \mathrm{Ma}, 2000 \mathrm{Ma}$, and 1480

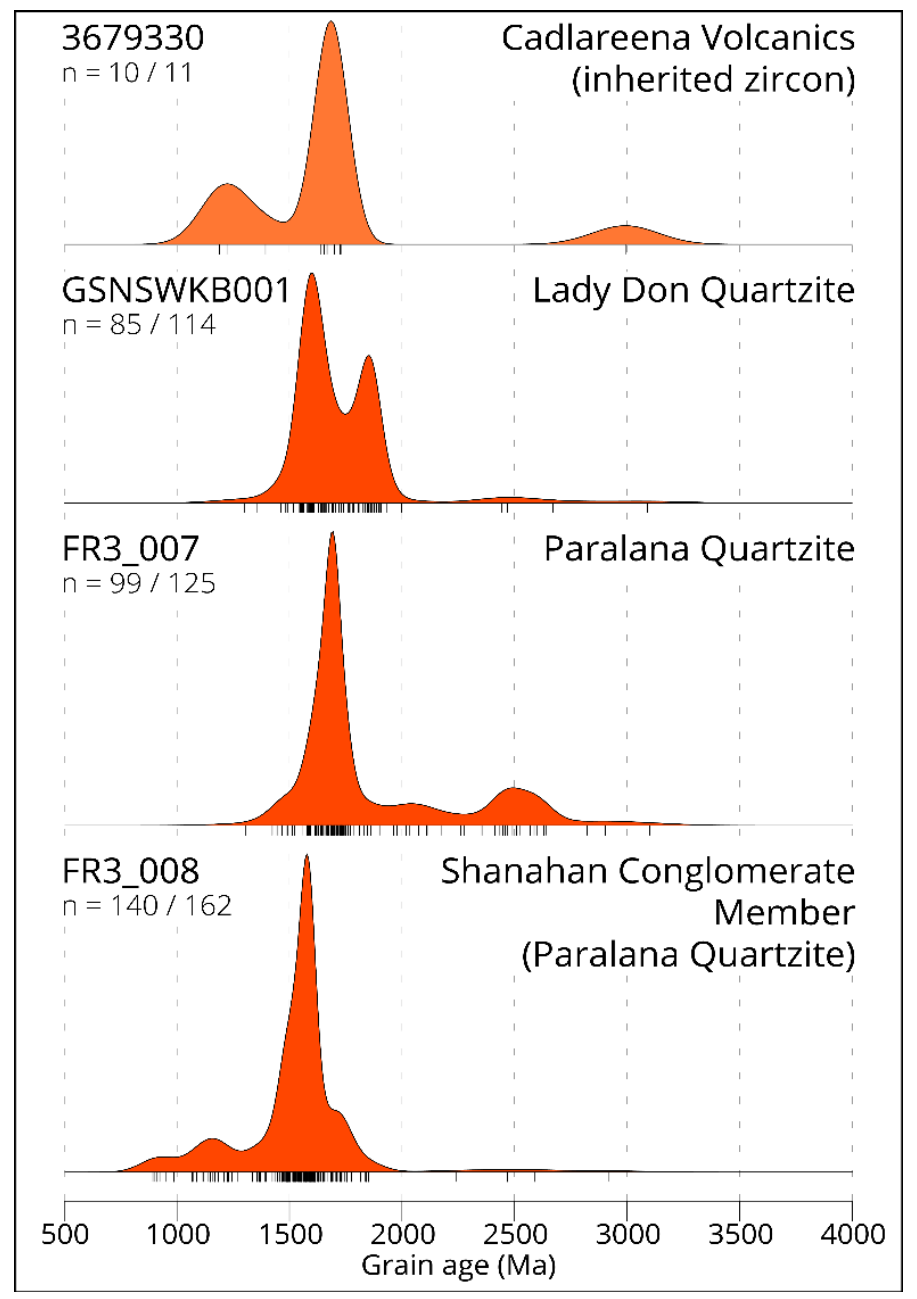

Figure 4 - Kernel density estimate plots of the four samples analysed in this study. These are in ascending stratigraphic order. Tick marks below each plot represent an analysis. $n=$ filtered analyses $/$ total analyses. Created using IsoplotR (Vermeesch 2018)

260 Ma. Three analyses lie outside these

261 populations, ranging from $3097 \pm 27$ Ma to $2819 \pm 60$ Ma.

A total of 114 analyses were conducted for sample GSNSWKB001. Of these, 85 analyses passed filtering parameters, with ages ranging between $3090 \pm 31$ Ma to $1302 \pm 23 \mathrm{Ma}$ [Figure 4]. The primary population peak of this sample is c. $1620 \mathrm{Ma}$, with a secondary peak c. $1840 \mathrm{Ma}$. These two peaks form a bimodal population ranging from $1999 \pm 32$ Ma to $1302 \pm 23 \mathrm{Ma}$. 
From the small quantity of sample that was crushed for sample 3679330, 11 zircons were obtained and analysed, with ten of these within filtering parameters. The oldest grain yielded an age of $2992 \pm 27 \mathrm{Ma}$, the youngest grain was $1189 \pm 18 \mathrm{Ma}$, and the remainder range between $1222 \pm 22$

272 Ma and $1725 \pm 24$ Ma with a cluster of

273 four grains C. 1680 Ma [Figure 4].

274 Lanthanoid concentrations are typical for

275 zircons, with several orders-of-magnitude

276 increase in concentration from light to

277 heavy elements, a slight negative

278 deviation in europium (Eu), and a positive

279 deviation in cerium (Ce) [Figure 5].

\section{Discussion}

\subsection{Provenance and} maximum depositional

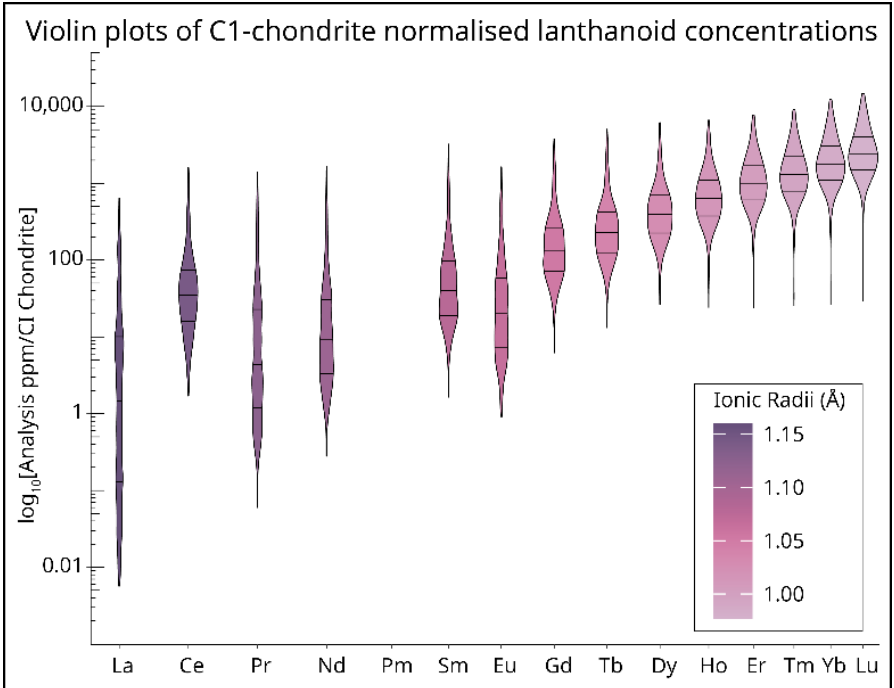

Figure 5 - Violin plots of CI chondrite (O'Neill 2016) normalised lanthanoids for all filtered zircon analysed in this study. X-axis is spaced by ionic radii (Shannon 1976) and ordered by atomic number. Black lines across the fill of each plot represent the $0.25,0.5$, and 0.75 quantiles. Bandwidth of the density estimates is calculated using the Botev algorithm from the Provenance package (Vermeesch et al. 2016). ages

\subsubsection{Paralana Quartzite, incl. Shanahan Conglomerate Member}

Samples FR3_007 and FR3_008 were both sampled from the Paralana Quartzite; however, FR3_008 was sampled from a stratigraphically lower position, mapped as the Shanahan Conglomerate Member. The MDA of the Paralana Quartzite will combine the results of both samples.

The youngest zircon in FR3_008 (analysis FR3_008 - 090, Figure 6) originally yielded ${ }^{207} \mathrm{~Pb} /{ }^{235} \mathrm{U}$, ${ }^{206} \mathrm{~Pb} /{ }^{238} \mathrm{U}$, and ${ }^{207} \mathrm{~Pb} /{ }^{206} \mathrm{~Pb}$ ages of $897 \pm 46 \mathrm{Ma}, 896 \pm 18 \mathrm{Ma}$, and $889 \pm 39 \mathrm{Ma}$, respectively. To verify the age obtained, this zircon was reanalysed on a subsequent analytical session with two additional analyses. The second analysis (FR3_008_run2 - 003, Figure 6) yielded ${ }^{207} \mathrm{~Pb} /{ }^{235} \mathrm{U}$, ${ }^{206} \mathrm{~Pb} /{ }^{238} \mathrm{U}$, and ${ }^{207} \mathrm{~Pb} /{ }^{206} \mathrm{~Pb}$ ages of $893 \pm 39 \mathrm{Ma}, 892 \pm 13 \mathrm{Ma}, 886 \pm 30 \mathrm{Ma}$, respectively. The third analysis (FR3_008_run2 - 004, Figure 6) yielded a younger discordant age likely due to a small 
inclusion that can be seen in Figure 6. The two concordant signals have Th/U ratios of $\sim 0.55$, and the discordant analysis has a Th/U ratio of $\sim$ 1.3. A concordia age of $893 \pm 9 \mathrm{Ma}$, MSWD 0.067, $p\left(\chi^{2}\right) 0.98$ is calculated from the two concordant analyses and a traditional uncertainty weighted mean yields a ${ }^{206} \mathrm{~Pb} /{ }^{238} \mathrm{U}$ age of $893 \pm 10$ Ma, MSWD 0.14 Ma, p( $\left.\chi^{2}\right)$ 0.71both age determinations propagate external uncertainties. The zircon is euhedral with simple regular growth zoning with a $\{101\}$ form (Corfu et al. 2003; Pupin 1980). Although one end of the zircon appears to have broken off, the aspect ratio is at least 3.3:1. As the concordia age is the statistically "most likely" age, (Ludwig 1998; Vermeesch 2021), uses the most amount of available analytical data from the multiple analyses of the single grain, and is in good agreement with individual calculated decay ages and the ${ }^{206} \mathrm{~Pb} /{ }^{238} \mathrm{U}$ weighted mean, this is used as the age of crystallisation, and subsequently the maximum depositional age for the Paralana Quartzite. This revises the maximum depositional age of the Paralana Quartzite down from $1177 \pm 28$ Ma (Lloyd et al. 2020) to $893 \pm 9$ Ma.

\section{Both samples, FR3_008 (Shanahan} Conglomerate Member) and FR3_007 (Paralana Quartzite), have an overlapping population of zircons c. 1800-1300 Ma, with their primary population peaks centred c. $1580 \mathrm{Ma}$ and c. $1690 \mathrm{Ma}$ respectively [Figure 4]. These primary zircon populations are likely to be derived

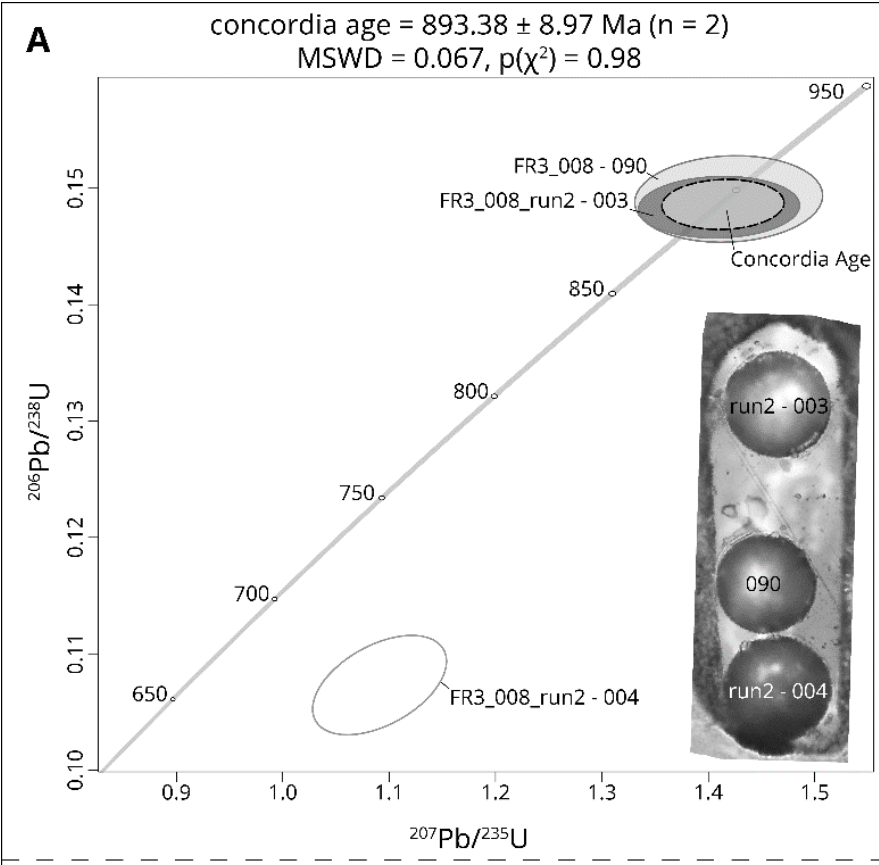

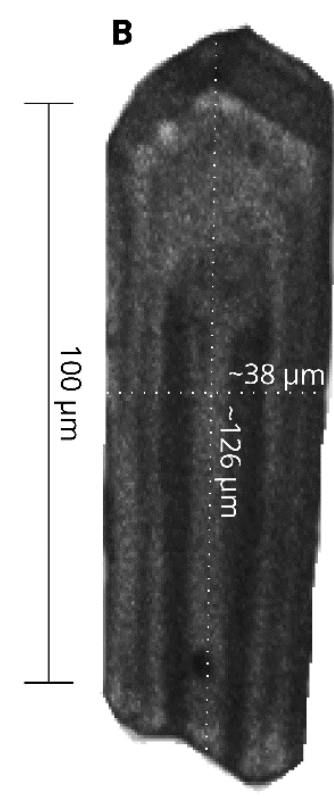

Aspect Ratio 3.3:1

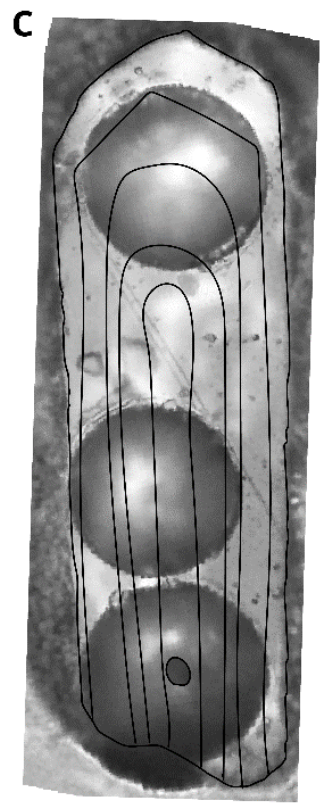

Figure 6-A) Concordia plot and age of the three spots analysed on the youngest single zircon for FR3_008 (Shanahan Conglomerate Member). Spots are labelled on the reflected light image. B) Cathodoluminescence image overlain with measurements for aspect ratio. C) Outlines of growth zones and inclusion overlain on reflected light image. Concordia plot generated using IsoplotR (Vermeesch 2018). locally from the Ninnerie Supersuite and/or Radium Creek Group (Armit et al. 2014; Kromkhun et al. 2013; Wade, CE 2011; Wade, CE et al. 2012). The two sample populations differ significantly with the direction of the population tails. Sample FR3_008 tails toward younger ages with an additional minor population peak c. $1150 \mathrm{Ma}$ and small cluster of grains c. $900 \mathrm{Ma}$ [Figure 4]. There are only four zircons older than c. 1850 Ma present in sample FR3_008. In contrast, sample FR3_007 tails toward older ages, with an additional minor population peak c. 2500 Ma [Figure 4] and no zircon younger 
than c. 1300 Ma. Zircons from the older tail of sample FR3_008, particularly the c. 2500 Ma, population are most likely derived from the Gawler Craton [Figure 7], namely the Mulgathing Complex and Sleaford Complex (Reid et al. 2014; Reid \& Payne 2017; Williams, MA \& Reid 2021), as has been previously suggested (Lloyd et al. 2020). The younger c. 1300-1050 Ma zircon population in sample FR3_008 is most likely derived from the Musgrave Province [Figure 7] (Howard et al. 2015; Smithies et al. 2008; Smithies et al. 2011; Smits et al. 2014; Wade, BP et al. 2008); however, they could alternately be sourced from a yet undiscovered but inferred Musgrave like, late Mesoproterozoic (c.

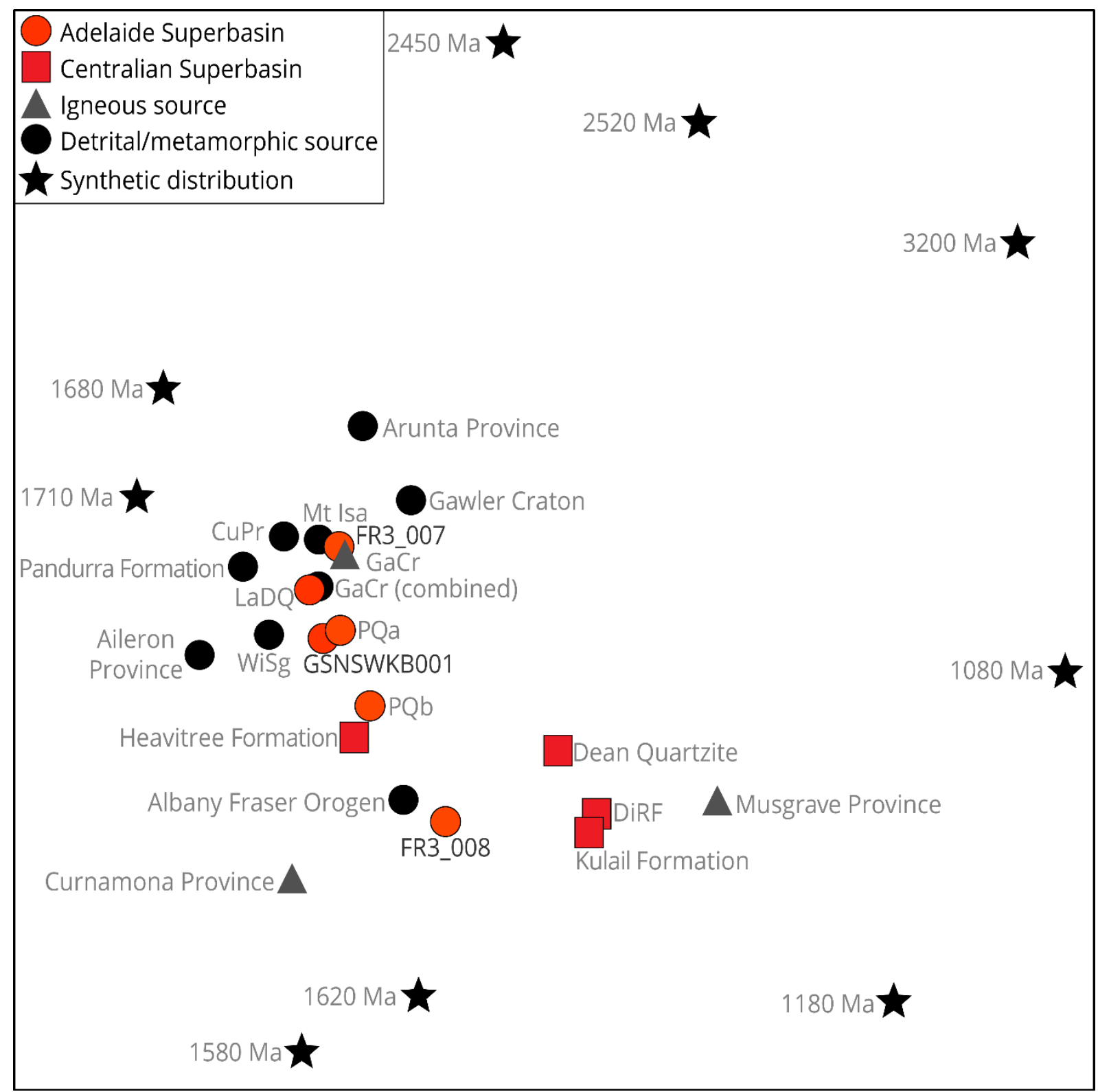

Figure 7 - Non-metric multidimensional scaling plot of samples analysed $(n>40)$ in this study (orange circles) with data from potential correlative formations of the Centralian Superbasin (red squares), potential source regions (black and grey circles and triangles), and synthetic distributions of main population peaks and key zircon growth events in the region. This plot shows relative similarity of all data to each other and are intended as a visual guide. Points that plot closer together suggest greater similarity. Axes are omitted as the algorithm used produces normalised values with no physical meaning and can be safely removed. Produced using IsoplotR (Vermeesch 2018). Abbreviations: $\mathrm{CuPr}=\mathrm{Curnamona}$ Province; $\mathrm{GaCr}=\mathrm{Gawler}$ Craton (combined signifies detrital, metamorphic, and igneous data); WiSg = Willyama Supergroup, DiRF = Dixon Range Formation, $\mathrm{PQ}$ = Paralana Quartzite data from this study and existing literature $(a=$ does not include Shanahan Conglomerate Member data, $b$ = includes Shanahan Conglomerate Member data). 
1300-1000 Ma) source to the east (Fergusson et al. 2007; Korsch et al. 2012; Mackay 2011; Wysoczanski \& Allibone 2004). The five youngest zircons present in sample FR3_008, younger than $1000 \mathrm{Ma}$, are enigmatic. They have no known local source terrane and given the euhedral to subhedral nature of these grains, and the breccia-conglomerate nature of the rock, it is unlikely they have been transported a great distance. It is possible these zircons are derived from an, as yet, undiscovered or previously destroyed minor magmatic sequence that would mark initial volcanism of the Adelaide Superbasin that precedes flood basalt emplacement. The zircon populations and lithological differences between the two samples, which were sampled approximately $350 \mathrm{~m}$ from each other, suggest a change in sediment source up stratigraphy to include a greater percentage of more distal source areas, and a loss of the younger source material.

\subsubsection{Lady Don Quartzite}

Sample GSNSWKB001 was sampled from the Lady Don Quartzite in New South Wales. Based on lithology and stratigraphic position it is believed that this formation and the Christine Judith Conglomerate are equivalents to the basal Callanna Group. The maximum depositional age obtained for sample GSNSWKB001 is $1497 \pm 52 \mathrm{Ma}$. There are a few zircons younger than this in the sample with the youngest being $1302 \pm 23 \mathrm{Ma}$; however, all these younger zircons are slightly discordant $(>2 \%,<10 \%)$. The sample's zircon age population is similar to that of the Paralana Quartzite [Figure 4, Figure 7] samples, with a primary population peak c. 1580 Ma but includes an additional prominent population peak c. $1850 \mathrm{Ma}$. There are a few zircons with ages older than $2000 \mathrm{Ma}$, with one c. $3090 \mathrm{Ma}$, one c. $2670 \mathrm{Ma}$, and two c. $2450 \mathrm{Ma}$. The primary zircon population c. $1580 \mathrm{Ma}$ is likely to be derived locally from the Ninnerie Supersuite and Radium Creek Group (Armit et al. 2014; Kromkhun et al. 2013; Wade, CE 2011; Wade, CE et al. 2012), lending support to stratigraphic correlation of the basal Adelaide Superbasin sequences [Figure 7]. The additional population c. 1850 Ma is potentially derived from the underlying Willyama Supergroup (Conor \& Preiss 2008; Page et al. 2005 ) that has been suggested to ultimately be derived from the Arunta Province (Barovich \& Hand 2008; Payne et al. 2006). The few zircon grains older than $2000 \mathrm{Ma}$ are also potentially derived from recycling of the underlying Willyama Supergroup. The rarity of these $>2000$ Ma zircons suggests direct transport from the Gawler Craton where these ages are found, namely the Mulgathing Complex, Sleaford Complex, and Cooyerdoo Granite (McAvaney 2012; Reid et al. 2014; Reid \& Payne 2017; Williams, MA \& Reid 2021), is unlikely.

\subsubsection{Cadlareena Volcanics}

The small Cadlareena Volcanics sample, 3679330 , only yielded 10 zircons that are all interpreted to be inherited/detrital as there is significant spread with no apparent clustering in the individual ages [Figure 4], and most of the zircon are subhedral and fragmented. The sample's physical appearance suggests that the rock is a silicified, intermediate volcano-sedimentary rock, so this result is unsurprising. From this we interpret a maximum depositional age of $1189 \pm 18 \mathrm{Ma}$. The ages of the zircon align with those found in the broader region, namely that of the Pitjantjatjara Supersuite of the Musgrave Province (Close 2013; Smithies et al. 2011) and the Tunkillia Suite of the Gawler Craton (Hand et al. 2007; Morrissey et al. 2019; Payne et al. 2010). 


\subsubsection{Comparison to basal Central Superbasin sequences}

The Centralian Superbasin developed as an intracontinental basin coeval with the Adelaide Superbasin (Munson et al. 2013; Walter et al. 1995), which developed relatively independently from each other (Preiss 2000). Geochronologic control, and thus correlation, of several stratigraphic units across the lower Adelaide Superbasin and Centralian Superbasin remain poor (Lloyd et al. 2020; Normington \& Donnellan 2020). However, the lowermost units are commonly correlated based on stratigraphic similarity and position (Drexel et al. 1993; Normington \& Donnellan 2020; Preiss 1987; Walter et al. 1995). In the Centralian Superbasin these formations are the Heavitree Formation, Dean Quartzite, Vaughn Springs Quartzite, Amesbury Quartzite, Munyu Sandstone, and Kulail Sandstone (Haines \& Allen 2017; Normington \& Donnellan 2020; Normington \& Edgoose 2018). These are thought to be equivalents to the Adelaide Superbasin formations from which samples analysed in this study were obtained. When the detrital zircon age populations are compared, two main groupings appear, the units of the Centralian Superbasin form one group separate from those of the Adelaide Superbasin [Figure 7]. This suggests that the two basins received detritus from differing sources. However, two exceptions occur, the Heavitree Formation and the Shanahan Conglomerate Member. These two units both plot [Figure 7] as an intermediary to the more obvious groupings of the Centralian Superbasin and Adelaide Superbasin sequences, suggesting a shared or similar primary detritus source. This is more easily explained for the Heavitree Formation, a relatively mature sandy unit, as the Arunta region, which has somewhat similar zircon age populations as the Gawler Craton, is inferred to be a major source of detritus for the Heavitree Formation (Al-Kiyumi 2018; Maidment et al. 2007). This intermediary position on [Figure 7] is much harder to reconcile for the Shanahan Conglomerate Member, as this unit is an immature, breccia-conglomerate, and is unlikely to have received detritus from distal sources, and as stated earlier, no local source of young zircon is known. The lends some support to the notion of a potential (Fergusson et al. 2007; Korsch et al. 2012; Mackay 2011; Wysoczanski \& Allibone 2004) Stenian-Tonian source to the east.

\subsection{Zircon trace element geochemistry}

Zircon trace element chemistry, particularly of the lanthanoids, uranium $(U)$, thorium (Th), yttrium ( $Y$ ), oxygen (O), and hafnium ( $\mathrm{Hf})$, can be useful in understanding their petrogenesis and provenance, and for crustal evolution (Campbell et al. 2020; Fernandes et al. 2021; Grimes, Craig B. et al. 2009; Grimes, C. B. et al. 2007; Grimes, C. B. et al. 2015; Hawkesworth \& Kemp 2006; Verdel et al. 2021). While lanthanoid geochemistry is not thought to be particularly useful in assisting with provenance determinations (Hoskin \& Ireland 2000), it is useful at a broader scale for understanding the continental history of a region. Here we make general observations about the trace element geochemistry of detrital zircon from the lowermost Adelaide Superbasin analysed in this study.

First, as a straightforward measure of continental or oceanic affinity for zircon generation, one can use U/Yb plotted against Y (Grimes, C. B. et al. 2007; Grimes, C. B. et al. 2015). All zircons analysed 
420 in this study are inferred to have been

421 generated in continental crust as shown by

422 [Figure 8]. C1 chondrite normalised (O'Neill

423 2016) concentrations of lanthanoids are

424 typical of zircon [Figure 5] with a positive

425 pattern slope (decreasing $\lambda 1$ values) from

426 light to heavy lanthanoids, a positive cerium

427 anomaly, and negative europium anomaly

428 (Hoskin \& Ireland 2000; Hoskin \&

429 Schaltegger 2003). Nearly all zircons have a

$430 \mathrm{Th} / \mathrm{U}>0.07$ and are inferred to be originally

431 generated as magmatic rather than

432 metamorphic zircon (Collins et al. 2004;

433 Rubatto 2002). There is no apparent trend

434 in lanthanoid pattern slope or curvature

435 [Figure 9], denoted as $\lambda 1$ (linear slope), $\lambda 2$

436 (quadratic slope), and $\lambda 3$ (cubic slope)

437 (Anenburg 2020), with time or sample. Both

438 Eu and Ce anomalies (denoted by Eu* and

$439 \mathrm{Ce}^{\star}$ ) show a significant spread through time.

440 However, while statistical confidence is

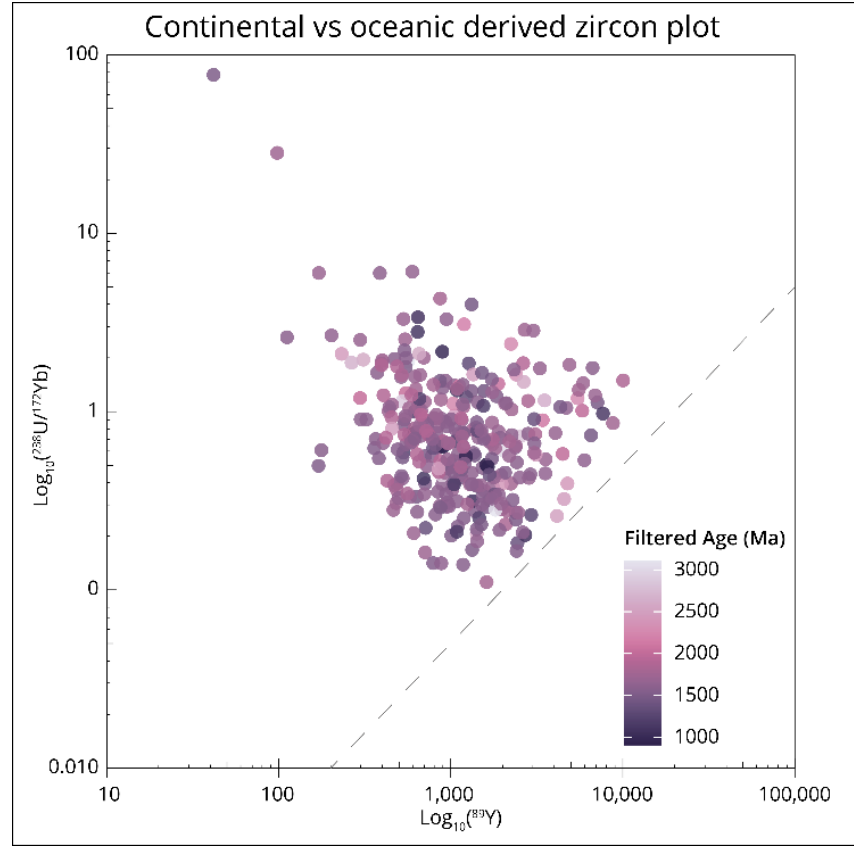

Figure 8 - Plot based on (Grimes, C. B. et al. 2007) used as an indicator of zircon crustal origin. This plots $\mathrm{Y}$ against $\mathrm{U} / \mathrm{Yb}$, with the dashed reference line dividing the "oceanic" (below line) and "continental" (above line) fields. All data plot above the reference line, suggesting zircon formation in crust of continental affinity.

Coloured by filtered age where light is older and darker is younger.

441 limited due to the low number of samples $<1000 \mathrm{Ma}$, it is observed that these generally have low Eu*

442 and $\mathrm{Ce}^{*}$ values ("low" is used as in Verdel et al. 2021, i.e. "strongly negative"). The positive

443 correlation of low Eu* and $\mathrm{Ce}^{*}$ values may suggest crystallisation in reduced conditions, thick crust,

444 sediment incorporation, deep mantle plume, effects of fractional crystallisation, and/or competition

445 with plagioclase and/or monazite (Verdel et al. 2021). The slight increase in Yb/U [Figure 9] in these

446 younger zircons suggests the addition of MORB like, or juvenile mantle-derived magmatism, which is

447 consistent with this type of magmatism accompanying Rodinia rifting. 


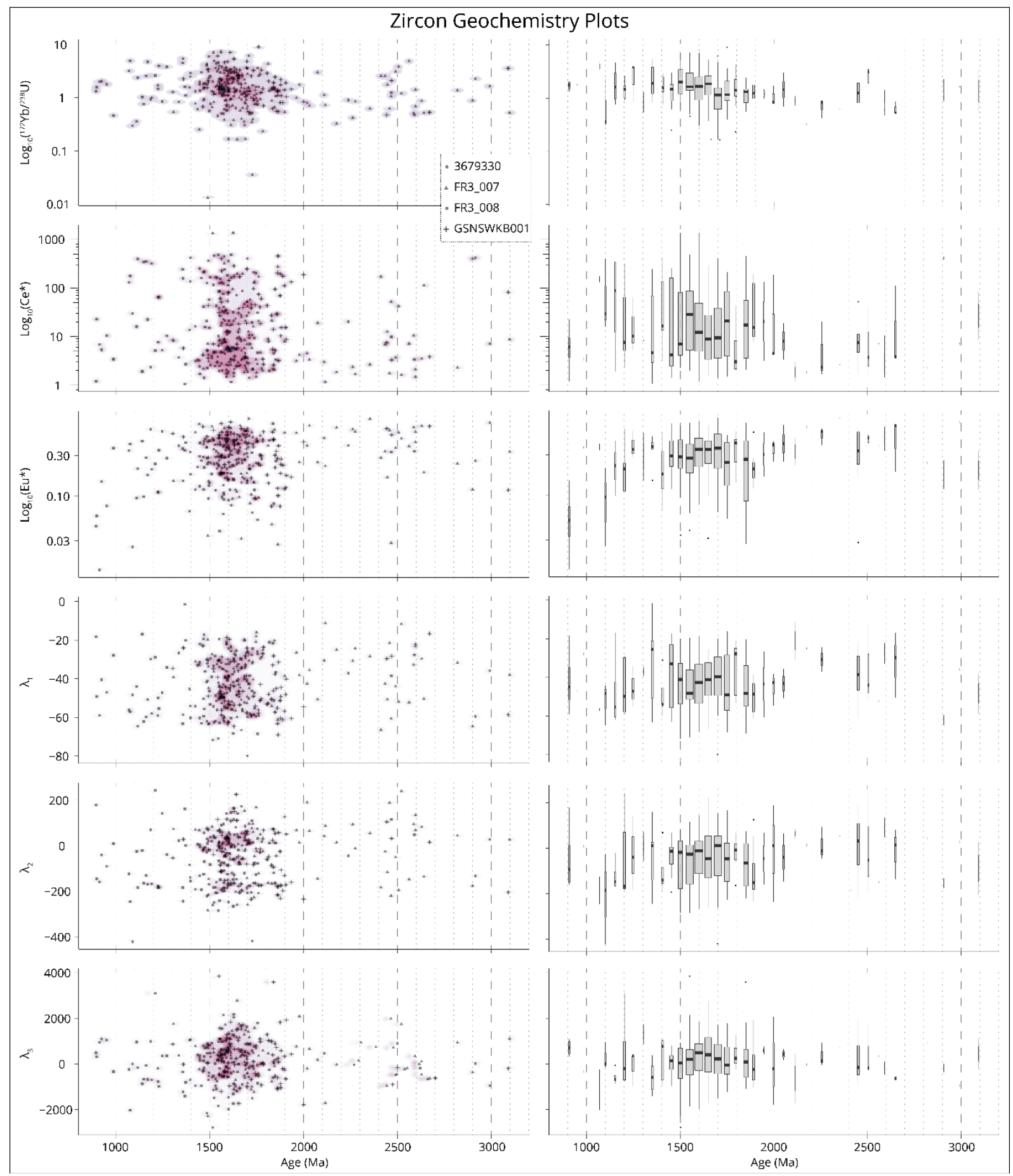

Figure 9 - Key zircon geochemistry plots for zircon analysed in this study. Left: Scatter plots underlain with 2D density estimation. Right: 50 million year binned boxplots with width scaled by the count of values in the bin. Top to bottom: $\mathrm{Yb} / \mathrm{U}, \mathrm{Ce}$, $\mathrm{Eu}^{*}$ and $\lambda 1-3 . \lambda 1-3$ are measures of lanthanoid pattern shapes, with $\lambda 1-3$ representing the linear slope, quadratic slope, and cubic slope, respectively. $\mathrm{Ce}^{\star}$, Eu* and $\lambda 1-3$ are calculated using BLambdaR (Anenburg \& Williams 2021).

\subsection{Willouran Large Igneous Province and Palaeogeography}

Previous authors (Li \& Powell 2001; Li et al. 1995; Mackay 2011; Wang, X-C et al. 2010) have based on igneous geochemistry, palaeomagnetic poles, and geochronology. These authors advocated 
for a link between southeast Proterozoic Australia and South China within Rodinia, the "missing link" model (Li et al. 1995). Wen and co-authors (Wen et al. 2017; Wen et al. 2018) developed an alternative missing link model placing Tarim between Australia and Laurentia instead of South China. However, an increasing number of studies examining detrital zircon (e.g., Cawood et al. 2020; Cawood et al. 2018; Hui et al. 2021; Wang, P et al. 2020), geodynamic and kinematic studies (e.g., Merdith et al. 2017a; Merdith et al. 2017b; Wu et al. 2021), and a recent comprehensive review and update to palaeomagnetic poles (Park et al. 2021) suggest that this position of South China (or Tarim) within the centre of Rodinia is unlikely. Further, this infers that the Willouran LIP and Guibei LIP are not spatially linked as has been previously suggested (Li \& Powell 2001; Li et al. 1995; Mackay 2011; Wang, X-C et al. 2010; Werner et al. 2018). The new detrital zircon data in this study further supports that the missing link model with Tarim or South China for Rodinia is unlikely. Our detrital zircon data [Figure 4] lack the prominent c. 800 Ma population that is present in samples from Tarim (Wang, P et al. 2020) and South China (Cawood et al. 2013; Cawood et al. 2018). Our data also preserve prominent populations at c. $1580 \mathrm{Ma}$ and c. $1840 \mathrm{Ma}$ that are not prominent within samples from either Tarim or South China.

\subsection{Early evolution of the Adelaide Superbasin}

Much of the Callanna Group has been either eroded, tectonically dismembered or disrupted by diapirs, and geochronologic controls on deposition remain poor. There are also limited seismic surveys that cross the Adelaide Superbasin (Korsch \& Kositcin 2010), and none over key areas where good stratigraphic control on the Callanna Group is possible (e.g., Willouran Ranges). This makes reconstructing the earliest sequences of the Adelaide Superbasin and its evolution particularly difficult. Here, using existing research on the basin, drawing on literature concerning modern (e.g., East African Rift: Boone et al. 2021; Corti 2009; Keranen \& Klemperer 2008; Purcell 2018; Varet 2018; Williams, FM 2016; Zwaan et al. 2020) and ancient (e.g., Midcontinent Rift: Allen et al. 2006; Stein et al. 2018) rift systems, and new detrital zircon data presented in this paper, we present an updated model for the early evolution of the Adelaide Superbasin.

Initiation of deposition within the Adelaide Superbasin began sometime between $893 \pm 9 \mathrm{Ma}$ and $\mathrm{c}$. $830 \mathrm{Ma}$. The initial, thin, and geographically restricted, mostly brecciated/conglomeratic clastic sediments (e.g., Shanahan Conglomerate Member) were likely deposited in a series of small, somewhat asymmetric half grabens with a local detrital source that contain enigmatic young $(<1000$ $\mathrm{Ma}$ ) zircons. The half grabens are thought to have developed by lithospheric thinning under an initial pulse of minor extension focussed along pre-existing crustal weaknesses (e.g., Norwest Fault, IsanOlarian orogen: Conor \& Preiss 2008; Mackay 2011; Meaney 2017; Morrissey et al. 2013; Nordsvan et al. 2018; Rutherford et al. 2007; Tiddy \& Giles 2020; Volante et al. 2020). This initial extension was most probably a result of far-field forces (Cawood et al. 2016), although a mantle plume may have played some role through thermal doming (Hill et al. 1992) or lithospheric weakening. Tectonic quiescence followed, with stable subsidence in the newly created rift, culminating with deposition of alluvial to fluvial sands and shallow water, sometimes stromatolitic, carbonates (e.g., Paralana Quartzite, Wywyana Formation). This is initially reflected in the change in zircon spectra of the Paralana Quartzite [Figure 4] to include a greater diversity of detrital sources before shallower water sediments were laid down. It is likely there was transtensional (Armit et al. 2012; Job 2011; Paul et al. 1999) movement along the Paralana Fault (and its splays) at this time, accounting for the 
significant thickness variation $(700 \mathrm{~m}$ ) of the Paralana Quartzite across the fault plane in the Arkaroola area (Preiss 1987). This interpretation differs from that of Preiss (2000), but agrees with Mackay (2011) and Job (2011), in that we consider the Arkaroola Subgroup to be early syn-rift, rather than pre-rift, deposition, but note that the amount of extension was minor. The Arkaroola Subgroup is here considered to reflect a sourceward-shifting facies tract (SFT) (Matenco \& Haq 2020), which fines upward after the initial phase of rift basin development [Figure 3]. Dyke emplacement (Gairdner Dolerite, Amata Dolerite) and extrusion of flood basalts (e.g., Wooltana Volcanics, Beda Basalt) occurs at the top of this first SFT and represents the first major phase of extension in the basin. The flood basalts were extruded in subaerial environments and may have originally formed a continuous sheet (Preiss 1987; 2000). After extrusion of the Willouran LIP, rift development continued, at an accelerated rate within well-developed grabens, with the deposition of cyclic clastic-carbonateevaporative sequences of the Curdimurka Subgroup [Figure 3]. This is consistent with detrital zircon and $\mathrm{Nd}$ provenance suggesting a gradual transition from evolved to juvenile, and broad to restricted detrital sources (Barovich \& Foden, 2000; Lloyd et al., 2020) over the long-term evolution of the basin. Evacuation of the magma chambers is thought to be partially responsible for major graben subsidence (Hillyard 1990). The Curdimurka Subgroup is at least $8 \mathrm{~km}$ thick, much greater in thickness than the Arkaroola Subgroup [Supplementary Figure S1], with significant variations across the basin. Magmatism is known to have continued during deposition of the Curdimurka Subgroup with bimodal volcanics known from the Willouran Ranges (Rook Tuff), a thin basalt flow in the Spalding Inlier, and xenoclasts of dolerite (thought to belong to the Curdimurka Subgroup) in diapirs/carbonate megabreccia zones (Preiss 1987). Constraints on the end of Curdimurka Subgroup deposition, and thus Callanna Group, remain poor. While an exact stratigraphic position has not been determined due to a lack of intact contact relationships (Fabris et al. 2005), the Oodla Wirra Volcanics provide the best determination of a maximum age for the final deposition of the Curdimurka Subgroup where two independent samples yielded ages of $798 \pm 5 \mathrm{Ma}$ and $799 \pm 4 \mathrm{Ma}$ (Fabris et al. 2005). This is within uncertainty of the $802 \pm 10$ Ma age of the Rook Tuff (Fanning et al. 1986) of the lower to mid Curdimurka Subgroup. However, the age determination from the Rook Tuff needs revising as is not reproducible due to the unavailability of the isotopic data from the original analyses, and increased precision and accuracy can be obtained on modern analytical equipment. The minimum age estimate for deposition of the Curdimurka Subgroup is constrained by the Boucaut Volcanics (Armistead et al. 2020) and a porphyry in a basal member of the Skillogalee Dolomite (Preiss et al. 2009) to c. 790 Ma. The exact stratigraphic position of the Boucaut Volcanics remains to be resolved (Lloyd et al. 2020); however, the position of the Skillogalee Dolomite is well constrained. As such, the Callanna Group-Burra Group transition must occur between c. $800 \mathrm{Ma}$ and c. $790 \mathrm{Ma}$ and allow for deposition of the upper Curdimurka Subgroup and entire Emeroo Subgroup. Deposition of the Emeroo Subgroup marks a southward propagation of the Adelaide Rift Complex during upper Curdimurka Subgroup times, with the most southerly deposition occurred near Spalding (Preiss 1987; 2000). A renewed pulse of magmatism (e.g., Boucaut Volcanics, Jarrold Basalt Member, Kooringa Member) occurs at c. $790 \mathrm{Ma}$ (Armistead et al. 2020; Preiss et al. 2009) in the southern and eastern areas of the basin and likely marks a southern shift in tectonic activity and a period of

536 In this model the rift system did not develop as a classic triple junction system through apical extension as was suggested by von der Borch (1980) and Zhao et al. (1994). Instead, the northern and central areas of the Adelaide Rift Complex initiated as an intra-continental rift that formed along 
pre-existing crustal weakness and failed to progress to continental breakup, resulting in the present

540 day aulacogen. Later development of the Adelaide Rift Complex expanded the extent of the rift

541 system to the south with wider deposition of the Burra Group. This southern region is suggested to

542 represent the successful rift axis of the Adelaide Superbasin where the proto-Pacific later formed

543 (consistent with kinematic constraints suggested by Merdith et al. 2017b). In this model, the triple

544 junctions suggested by von der Borch (1980) are a result of the intersection of propagating rifts to

545 form a geometric triple junction.

546 This model is similar to recent ideas about the development of the Afar triple junction, where the Red

547 Sea meets the Gulf of Aden and the East African Rift system. Traditionally, this area has been viewed

548 as the classic triple junction rift-rift-rift system formed by apical extension away from the triple

549 junction centre (McKenzie et al. 1970; Tesfaye et al. 2003). However, the geological evidence

550 suggests that at least two of the three arms (Aden Rift, Ethiopian Rift) propagated inwards towards

551 the now seen geometric triple junction, and the chronology of the rift systems does not fit with plume

552 driven apical extension from a central point (e.g., Barberi et al. 1972; Corti 2009; Varet 2018; Zwaan

553 et al. 2020). It appears that the modern Afar triple junction is a geometric place where three rifts,

554 with their predetermined geometries, happened to cross rather than being the point of initiation (e.g.,

555 Barberi et al. 1972; Corti 2009; Varet 2018; Zwaan et al. 2020), similar to our model for the Adelaide

556 Rift Complex.

\section{Conclusions}

558 The development of the Adelaide Superbasin initiated between c. 890-830 Ma with the deposition of 559 the Arkaroola Subgroup in a series of structurally controlled half-grabens in what now constitutes the

560 Adelaide Rift Complex. These structures are likely a manifestation of northeast-southwest (present

561 day) orientated extensional strain from far-field forces, and potentially also stress from a mantle

562 plume. This phase of extension was limited, and tectonic quiescence followed until extrusion of the

563 Willouran Large Igneous Province (LIP). The Willouran LIP may have been the result of a mantle

564 plume, and its emplacement led to extensive rifting and subsequent deposition of the Curdimurka

565 Subgroup.

566 Key findings of this research are: 
- Revised constraints on timing of initial deposition within the Adelaide Superbasin, between $\geq 893 \pm 9 \mathrm{Ma}$ and c. $830 \mathrm{Ma}$.

- Identification of an enigmatic source of young (<1000 Ma) zircon, in the basal stratigraphic unit

- The Arkaroola Subgroup represents early, syn-rift, deposition within half-grabens, developed in an initial pulse of extension that likely exploited pre-existing crustal weakness.

- The central and northern Flinders Ranges formed the initial arm of the rift system, but failed to progress to continental breakup.

- Basal Centralian Superbasin and Adelaide Superbasin stratigraphic units had different primary detrital sources.

- Support for a potential late Mesoproterozoic source region to the east of the basin.

\section{Funding}

The Geological Survey of South Australia and the MinEx CRC funded this research. This research was supported by an Australian Government Research Training Program (RTP) Scholarship awarded to JCL.

\section{Supplementary Material}

Supplementary Figure S1 is available as both and EPS file an PNG file hosted on Figshare: https://doi.org/10.6084/m9.figshare.19153274

\section{Data Availability}

Complete data for this publication are freely available for download from Figshare at the following links. These datasets contain all the U-Pb geochronology data, trace element data, and basic sample metadata.

Zircon and NIST standards data for all analytical sessions: https://doi.org/10.6084/m9.figshare.18131432

Callanna Group (this study only) detrital zircon data: https://doi.org/10.6084/m9.figshare.18131420 Zircon CL images: https://doi.org/10.6084/m9.figshare.19181024

\section{Code Availability}

$\mathrm{R}$ code used to generate the zircon geochemistry plots is available on GitHub at https://github.com/jarredclloyd/zircon-trace-element-plots

\section{CRediT author statement}

Jarred C. Lloyd: Conceptualisation, investigation, writing - original draft, writing - review \& editing, methodology, formal analysis, data curation, visualisation. Morgan L. Blades: Investigation, writing review \& editing. Alan S. Collins: Conceptualisation, funding acquisition, supervision, investigation, writing - review \& editing. Sarah E. Gilbert: Formal analysis, methodology, investigation, writing - 
601 review \& editing. Kathryn J. Amos: Conceptualisation, funding acquisition, supervision, writing -

602 review \& editing.

\section{Acknowledgements}

604 We acknowledge the Adnyamathanha, Arabana, Banggarla, Kaurna, Kokatha, Kuyani, Ngadjuri and 605 Nukunu Peoples as the Traditional Owners and Custodians of the land on which this research is 606 conducted. We acknowledge and respect their deep feelings of attachment and spiritual relationship 607 to Country, and that their cultural and heritage beliefs are still as important to the living people today.

608 The authors acknowledge the instruments and scientific and technical assistance of Microscopy

609 Australia at Adelaide Microscopy, The University of Adelaide, a facility that is funded by the

610 University, and State and Federal Governments. Particular thanks to Aoife McFadden for their

611 assistance with CL imaging.

612 We also thank Dr Wolfgang Preiss (Geological Survey of South Australia; University of Adelaide) for 613 his expertise on the Adelaide Superbasin, James Nankivell, and Georgina Virgo (University of

614 Adelaide) for their assistance with fieldwork. Chris Folkes (Geological Survey of New South Wales)

615 and John Greenfield (formerly GSNSW) are thanked for sharing expertise of the New South Wales

616 sequences.

617 This work is conducted with the appropriate permissions and scientific permits from the relevant 618 stakeholders. 


\section{References}

620

621

622

623

624

625

626

627

628

629

630

631

632

633

634

635

636

637

638

639

640

641

642

643

644

645

646

647

648

649

650

651

652

653

654

655

656

657

658

659

660

661

662

663

664

665

666

667

668

669

670

671

672

Al-Kiyumi, M 2018, 'Constraining the age and provenance of the basal quartzites of the Centralian Superbasin', Department of Earth Sciences, Honours Thesis thesis, Bachelor of Science (Honours) thesis, University of Adelaide, Adelaide, South Australia, $<$ http://hdl.handle.net/2440/130321>.

Alcott, LJ, Krause, AJ, Hammarlund, EU, Bjerrum, CJ, Scholz, F, Xiong, Y, Hobson, AJ, Neve, L, Mills, BJW, März, C, Schnetger, B, Bekker, A \& Poulton, SW 2020, 'Development of Iron Speciation Reference Materials for Palaeoredox Analysis', Geostandards and Geoanalytical Research, vol. 44, no. 3, 2020/09/01, pp. 581-591, DOI: 10.1111/ggr.12342.

Allen, DJ, Braile, LW, Hinze, WJ \& Mariano, J 2006, 'Chapter 10 The midcontinent rift system, U.S.A.: A major proterozoic continental rift', in KH Olsen (ed.), Developments in Geotectonics, vol. 25, Elsevier, pp. 375-XIX.

Ambrose, GJ, Flint, RB \& Webb, AW 1981, Precambrian and Palaeozoic Geology of the Peake and Denison Ranges, Bulletin, 50, Geological Survey of South Australia, Adelaide, South Australia.

Anenburg, M 2020, 'Rare earth mineral diversity controlled by REE pattern shapes', Mineralogical Magazine, vol. 84, no. 5, pp. 629-639, DOI: 10.1180/mgm.2020.70.

Anenburg, M \& Williams, MJ 2021, 'Quantifying the Tetrad Effect, Shape Components, and Ce-Eu-Gd Anomalies in Rare Earth Element Patterns', Mathematical Geosciences, DOI: 10.1007/s11004-021-09959-5.

Armistead, SE, Collins, AS, Buckman, S \& Atkins, R 2020, 'Age and geochemistry of the Boucaut Volcanics in the Neoproterozoic Adelaide Rift Complex, South Australia', Australian Journal of Earth Sciences, pp. 1-10, DOI: 10.1080/08120099.2021.1840435.

Armit, RJ, Betts, PG, Schaefer, BF \& Ailleres, L 2012, 'Constraints on long-lived Mesoproterozoic and Palaeozoic deformational events and crustal architecture in the northern Mount Painter Province, Australia', Gondwana Research, vol. 22, no. 1, pp. 207-226, DOI: 10.1016/j.gr.2011.11.003.

Armit, RJ, Betts, PG, Schaefer, BF, Pankhurst, MJ \& Giles, D 2014, 'Provenance of the Early Mesoproterozoic Radium Creek Group in the northern Mount Painter Inlier: Correlating isotopic signatures to inform tectonic reconstructions', Precambrian Research, vol. 243, 2014/04/01/, pp. 63-87, DOI: 10.1016/j.precamres.2013.12.022.

Barberi, F, Tazieff, H \& Varet, J 1972, 'Volcanism in the Afar depression: Its tectonic and magmatic significance', Tectonophysics, vol. 15, no. 1, 1972/10/01/, pp. 19-29, DOI: 10.1016/00401951(72)90046-7.

Barovich, KM \& Hand, M 2008, 'Tectonic setting and provenance of the Paleoproterozoic Willyama Supergroup, Curnamona Province, Australia: Geochemical and Nd isotopic constraints on contrasting source terrain components', Precambrian Research, vol. 166, no. 1, 2008/10/30/, pp. 318-337, DOI: 10.1016/j.precamres.2007.06.024.

Bogdanova, SV, Pisarevsky, SA \& Li, Z-X 2009, 'Assembly and Breakup of Rodinia (Some results of IGCP project 440)', Stratigraphy and Geological Correlation, vol. 17, no. 3, Jun, pp. 259-274, DOI: $10.1134 /$ S0869593809030022.

Boone, SC, Balestrieri, M-L \& Kohn, B 2021, 'Tectono-Thermal Evolution of the Red Sea Rift', Frontiers in Earth Science, vol. 9, DOI: 10.3389/feart.2021.713448.

Brookfield, ME 1993, 'Neoproterozoic Laurentia-Australia fit', Geology, vol. 21, no. 8, pp. 683-686, DOI: 10.1130/0091-7613(1993)021<0683:NLAF>2.3.CO;2.

Callen, RA 1990, Curnamona, 1:250 000 Geological Series-Explanatory Notes, Department of Mines and Energy, Adelaide, South Australia.

Campbell, MJ, Rosenbaum, G, Allen, CM \& Spandler, C 2020, 'Continental crustal growth processes revealed by detrital zircon petrochronology: Insights from Zealandia', Journal of Geophysical Research: Solid Earth, vol. n/a, no. n/a, p. e2019JB019075, DOI: doi:10.1029/2019JB019075.

Cawood, PA, Strachan, RA, Pisarevsky, SA, Gladkochub, DP \& Murphy, JB 2016, 'Linking collisional and accretionary orogens during Rodinia assembly and breakup: Implications for models of supercontinent cycles', Earth and Planetary Science Letters, vol. 449, pp. 118-126, DOI: 10.1016/j.epsl.2016.05.049. 
Cawood, PA, Wang, W, Zhao, T, Xu, Y, Mulder, JA, Pisarevsky, SA, Zhang, L, Gan, C, He, H, Liu, H, Qi, L, Wang, Y, Yao, J, Zhao, G, Zhou, M-F \& Zi, J-W 2020, 'Deconstructing South China and consequences for reconstructing Nuna and Rodinia', Earth-Science Reviews, vol. 204, 2020/05/01/, p. 103169, DOI: 10.1016/j.earscirev.2020.103169.

Cawood, PA, Wang, Y, Xu, Y \& Zhao, G 2013, 'Locating South China in Rodinia and Gondwana: A fragment of greater India lithosphere?', Geology, vol. 41, no. 8, pp. 903-906, DOI: 10.1130/G34395.1.

Cawood, PA, Zhao, G, Yao, J, Wang, W, Xu, Y \& Wang, Y 2018, 'Reconstructing South China in Phanerozoic and Precambrian supercontinents', Earth-Science Reviews, vol. 186, 2017/07/03/, pp. 173-194, DOI: 10.1016/j.earscirev.2017.06.001.

Close, DF 2013, 'Chapter 21: Musgrave Province', in M Ahmad \& TJ Munson (eds), Geology and mineral resources of the Northern Territory, Northern Territory Geological Survey, Northern Territory.

Coats, RP \& Blissett, AH 1971, Regional and Economic Geology of the Mount Painter Province, Bulletin, 43, Geological Survey of South Australia, Adelaide, South Australia.

Collins, AS, Blades, ML, Merdith, AS \& Foden, JD 2021, 'Closure of the Proterozoic Mozambique Ocean was instigated by a late Tonian plate reorganization event', Communications Earth \& Environment, vol. 2, no. 1, 2021/04/20, p. 75, DOI: 10.1038/s43247-021-00149-z.

Collins, AS, Reddy, SM, Buchan, C \& Mruma, A 2004, 'Temporal constraints on Palaeoproterozoic eclogite formation and exhumation (Usagaran Orogen, Tanzania)', Earth and Planetary Science Letters, vol. 224, no. 1, 2004/07/30/, pp. 175-192, DOI: 10.1016/j.epsl.2004.04.027.

Conor, CHH \& Preiss, WV 2008, 'Understanding the 1720-1640Ma Palaeoproterozoic Willyama Supergroup, Curnamona Province, Southeastern Australia: Implications for tectonics, basin evolution and ore genesis', Precambrian Research, vol. 166, no. 1, 2008/10/30/, pp. 297317, DOI: 10.1016/j.precamres.2007.08.020.

Cooper, PF \& Tuckwell, KD 1971, 'The upper Precambrian Adelaidean of the Broken Hill area-a new subdivision', Quarterly Notes - Geological Survey of New South Wales, vol. 3, pp. 8-16.

Corfu, F, Hanchar, JM, Hoskin, PWO \& Kinny, P 2003, 'Atlas of zircon textures', Reviews in Mineralogy and Geochemistry, vol. 53, pp. 469-500, DOI: 10.2113/0530469.

Corti, G 2009, 'Continental rift evolution: From rift initiation to incipient break-up in the Main Ethiopian Rift, East Africa', Earth-Science Reviews, vol. 96, no. 1-2, pp. 1-53, DOI: 10.1016/j.earscirev.2009.06.005.

Counts, JW 2016, 'Sedimentology, provenance, and salt-sediment interaction in the Ediacaran Pound subgroup, Flinders Ranges, South Australia', Australian School of Petroleum, Doctoral Thesis thesis, Doctor of Philosophy thesis, University of Adelaide, Adelaide, South Australia, viewed 4/09/2018, <http://hdl.handle.net/2440/105869>.

Counts, JW 2017, The Adelaide Rift Complex in the Flinders Ranges: geologic history, past investigations and relevant analogues, Report Book, no. 2017/00016, Geological Survey of South Australia, Department of Premier and Cabinet, Adelaide, South Australia, $<$ https://sarigbasis.pir.sa.gov.au/WebtopEw/ws/samref/sarig1/wcir/Record? $r=0 \& m=1 \& w=c a$ tno=2039731>.

Cowley, WM 2020, 'Geological setting of exceptional geological features of the Flinders Ranges', Australian Journal of Earth Sciences, pp. 1-23, DOI: 10.1080/08120099.2020.1748109.

Crawford, AJ \& Hillyard, D 1990, 'Geochemistry of Late Proterozoic tholeiitic flood basalts, Adelaide Geosyncline, South Australia', in JB Jago \& PS Moore (eds), The Evolution of a Late Precambrian Early Palaeozoic Rift Complex: The Adelaide Geosyncline, Geological Society of Australia Inc., Sydney, New South Wales, pp. 49-67.

Dalziel, IWD 1997, 'OVERVIEW: Neoproterozoic-Paleozoic geography and tectonics: Review, hypothesis, environmental speculation', GSA Bulletin, vol. 109, no. 1, pp. 16-42, DOI: 10.1130/0016-7606(1997)109<0016:ONPGAT>2.3.C0;2.

Drexel, JF \& Preiss, WV (eds) 1995, The geology of South Australia, vol. 2, The Phanerozoic, Bulletin, 54 , Geological Survey of South Australia, South Australia.

Drexel, JF, Preiss, WV \& Parker, AJ (eds) 1993, The geology of South Australia, vol. 1, The Precambrian, Bulletin, 54, Geological Survey of South Australia, South Australia. 
Dröllner, M, Barham, M, Kirkland, CL \& Ware, B 2021, 'Every zircon deserves a date: selection bias in detrital geochronology', Geological Magazine, vol. 158, no. 6, pp. 1135-1142, DOI: $10.1017 / \mathrm{s} 0016756821000145$.

Fabris, AJ, Constable, SA, Conor, CHH, Woodhouse, A, Hore, SB \& Fanning, M 2005, 'Age, origin, emplacement and mineral potential of the Oodla Wirra Volcanics, Nackara Arc, central Flinders Ranges', MESA Journal, vol. 37, pp. 44-52, https://sarigbasis.pir.sa.gov.au/WebtopEw/ws/samref/sarig1/wci/Record?r=0\&m=1\&w=catn $0=2025119$.

Fanning, CM, Ludwig, KR, Forbes, BG \& Preiss, WV 1986, 'Single and multiple grain U-Pb zircon analyses for the early Adelaidean Rook Tuff, Willouran Ranges, South Australia', in Eighth Australian Geological Convention: "Earth Resources in Space and Time", Geological Society of Australia, Sydney, New South Wales, pp. 71-72.

Fergusson, CL, Henderson, RA, Fanning, CM \& Withnall, IW 2007, 'Detrital zircon ages in Neoproterozoic to Ordovician siliciclastic rocks, northeastern Australia: implications for the tectonic history of the East Gondwana continental margin', Journal of the Geological Society, vol. 164, no. 1, pp. 215-225, DOI: 10.1144/0016-76492005-136.

Fernandes, CM, Duffles Teixeira, PA \& Mendes, JC 2021, 'Constraining crystallization conditions during the Cambro-Ordovician post-collisional magmatism at Araçuaí belt (SE Brazil): Zircon as key petrologic witness', Journal of South American Earth Sciences, vol. 108, DOI: 10.1016/j.jsames.2021.103235.

Foden, JD, Elburg, MA, Dougherty-Page, J \& Burtt, A 2006, 'The timing and duration of the Delamerian orogeny: Correlation with the Ross Orogen and implications for Gondwana assembly', Journal of Geology, vol. 114, no. 2, Mar, pp. 189-210, DOI: 10.1086/499570.

Foden, JD, Elburg, MA, Turner, S, Clark, C, Blades, ML, Cox, G, Collins, AS, Wolff, K \& George, C 2020, 'Cambro-Ordovician magmatism in the Delamerian orogeny: Implications for tectonic development of the southern Gondwanan margin', Gondwana Research, 2020/01/16/, DOI: 10.1016/j.gr.2019.12.006.

Forbes, BG, Murrell, B \& Preiss, WV 1981, 'Subdivision of lower Adelaidean, Willouran Ranges', Quarterly Geological Notes, vol. 79, pp. 7-16.

Gernon, TM, Hincks, TK, Tyrrell, T, Rohling, EJ \& Palmer, MR 2016, 'Snowball Earth ocean chemistry driven by extensive ridge volcanism during Rodinia breakup', Nature Geoscience, vol. 9, no. 3, 2016/03/01, pp. 242-248, DOI: 10.1038/ngeo2632.

Grimes, CB, John, BE, Cheadle, MJ, Mazdab, FK, Wooden, JL, Swapp, S \& Schwartz, JJ 2009, 'On the occurrence, trace element geochemistry, and crystallization history of zircon from in situ ocean lithosphere', Contributions to Mineralogy and Petrology, vol. 158, no. 6, pp. 757-783, DOI: $10.1007 / \mathrm{s} 00410-009-0409-2$.

Grimes, CB, John, BE, Kelemen, PB, Mazdab, FK, Wooden, JL, Cheadle, MJ, Hanghøj, K \& Schwartz, JJ 2007, 'Trace element chemistry of zircons from oceanic crust: A method for distinguishing detrital zircon provenance', Geology, vol. 35, no. 7, pp. 643-646, DOI: 10.1130/G23603A.1.

Grimes, CB, Wooden, JL, Cheadle, MJ \& John, BE 2015, '“Fingerprinting” tectono-magmatic provenance using trace elements in igneous zircon', Contributions to Mineralogy and Petrology, vol. 170, no. 5, 2015/11/03, p. 46, DOI: 10.1007/s00410-015-1199-3.

Haines, PW \& Allen, HJ 2017, Geological reconnaissance of the southern Murraba Basin, Western Australia: revised stratigraphic position within the Centralian Superbasin and hydrocarbon potential, Record, no. 2017/4.

Halverson, GP, Hurtgen, MT, Porter, SM \& Collins, AS 2009, 'Neoproterozoic-Cambrian Biogeochemical Evolution', in C Gaucher, AN Sial, HE Frimmel \& GP Halverson (eds), Developments in Precambrian Geology, vol. 16, Elsevier, pp. 351-365.

Hand, M, Reid, A \& Jagodzinski, L 2007, 'Tectonic Framework and Evolution of the Gawler Craton, Southern Australia', Economic Geology, vol. 102, no. 8, pp. 1377-1395, DOI: 10.2113/gsecongeo.102.8.1377.

Hawkesworth, CJ \& Kemp, AIS 2006, 'Using hafnium and oxygen isotopes in zircons to unravel the record of crustal evolution', Chemical Geology, vol. 226, no. 3, 2006/02/28/, pp. 144-162, DOI: 10.1016/j.chemgeo.2005.09.018. 
Hearon IV, TE, Rowan, MG, Lawton, TF, Hannah, PT \& Giles, KA 2015, 'Geology and tectonics of Neoproterozoic salt diapirs and salt sheets in the eastern Willouran Ranges, South Australia', Basin Research, vol. 27, no. 2, 2015/04/01, pp. 183-207, DOI: 10.1111/bre.12067.

Hill, RI, Campbell, IH, Davies, GF \& Griffiths, RW 1992, 'Mantle Plumes and Continental Tectonics', Science, vol. 256, no. 5054, p. 186, DOI: 10.1126/science.256.5054.186.

Hillyard, D 1990, 'Willouran Basic Province: Stratigraphy of Late Proterozoic flood basalts, Adelaide Geosyncline, South Australia', in JB Jago \& PS Moore (eds), The Evolution of a Late Precambrian Early Palaeozoic Rift Complex: The Adelaide Geosyncline, Geological Society of Australia Inc., Sydney, New South Wales, pp. 34-48.

Hoffman, PF 1991, 'Did the Breakout of Laurentia Turn Gondwanaland Inside-Out?', Science, vol. 252, no. 5011, pp. 1409-1412, www.jstor.org/stable/2875916.

Horstwood, MSA, Košler, J, Gehrels, GE, Jackson, SE, McLean, NM, Paton, C, Pearson, NJ, Sircombe, KN, Sylvester, P, Vermeesch, P, Bowring, JF, Condon, DJ \& Schoene, B 2016, 'CommunityDerived Standards for LA-ICP-MS U-(Th-)Pb Geochronology - Uncertainty Propagation, Age Interpretation and Data Reporting', Geostandards and Geoanalytical Research, vol. 40, no. 3, 2016/09/01, pp. 311-332, DOI: 10.1111/j.1751-908X.2016.00379.x.

Hoskin, PWO \& Ireland, TR 2000, 'Rare earth element chemistry of zircon and its use as a provenance indicator', Geology, vol. 28, no. 7, pp. 627-630, DOI: 10.1130/00917613(2000)28<627:REECOZ>2.0.CO;2.

Hoskin, PWO \& Schaltegger, U 2003, 'The composition of zircon and igneous and metamorphic petrogenesis', Reviews in Mineralogy and Geochemistry, vol. 53, no. 1, pp. 27-62, DOI: 10.2113/0530027.

Howard, HM, Smithies, RH, Kirkland, CL, Kelsey, DE, Aitken, A, Wingate, MTD, Quentin de Gromard, R, Spaggiari, CV \& Maier, WD 2015, 'The burning heart - The Proterozoic geology and geological evolution of the west Musgrave Region, central Australia', Gondwana Research, vol. 27, no. 1, pp. 64-94, DOI: 10.1016/j.gr.2014.09.001.

Huang, Q, Kamenetsky, VS, McPhie, J, Ehrig, K, Meffre, S, Maas, R, Thompson, J, Kamenetsky, M, Chambefort, I, Apukhtina, O \& Hu, Y 2015, 'Neoproterozoic (ca. 820-830Ma) mafic dykes at Olympic Dam, South Australia: Links with the Gairdner Large Igneous Province', Precambrian Research, vol. 271, 2015/12/01/, pp. 160-172, DOI: 10.1016/j.precamres.2015.10.001.

Hui, B, Dong, Y, Zhang, F, Sun, S \& He, S 2021, 'Neoproterozoic active margin in the northwestern Yangtze Block, South China: new clues from detrital zircon U-Pb geochronology and geochemistry of sedimentary rocks from the Hengdan Group', Geological Magazine, vol. 158, no. 5, pp. 842-858, DOI: $10.1017 /$ S0016756820000898.

Jackson, SE, Pearson, NJ, Griffin, WL \& Belousova, EA 2004, 'The application of laser ablationinductively coupled plasma-mass spectrometry to in situ U-Pb zircon geochronology', Chemical Geology, vol. 211, no. 1-2, 2004/11/08/, pp. 47-69, DOI: 10.1016/j.chemgeo.2004.06.017.

Job, AL 2011, 'Evolution of the basal Adelaidean in the northern Flinders Ranges: deposition, provenance and deformation of the Callanna and lower Burra Groups', Department of Geology and Geophysics, Honours Thesis thesis, Bachelor of Science (Honours) thesis, University of Adelaide, Adelaide, South Australia, viewed 4/09/2018, <http://hdl.handle.net/2440/96175>.

Jochum, KP, Weis, U, Stoll, B, Kuzmin, D, Yang, Q, Raczek, I, Jacob, DE, Stracke, A, Birbaum, K, Frick, DA, Günther, D \& Enzweiler, J 2011, 'Determination of Reference Values for NIST SRM 610617 Glasses Following ISO Guidelines', Geostandards and Geoanalytical Research, vol. 35, no. 4, 2011/12/01, pp. 397-429, DOI: 10.1111/j.1751-908X.2011.00120.x.

Karlstrom, KE, Harlan, SS, Williams, ML, McLelland, J, Geissman, JW \& Ahäll, K-I 1999, 'Refining Rodinia: geologic evidence for the Australia-western US connection in the Proterozoic', GSA Today, vol. 9, no. 10, pp. 1-7.

Keeman, J, Turner, S, Haines, PW, Belousova, E, Ireland, T, Brouwer, P, Foden, J \& Wörner, G 2020 , 'New UPb, $\mathrm{Hf}$ and $\mathrm{O}$ isotope constraints on the provenance of sediments from the Adelaide Rift Complex - Documenting the key Neoproterozoic to early Cambrian succession', Gondwana Research, vol. 83, 2020/07/01/, pp. 248-278, DOI: 10.1016/j.gr.2020.02.005. 
Keranen, K \& Klemperer, SL 2008, 'Discontinuous and diachronous evolution of the Main Ethiopian Rift: Implications for development of continental rifts', Earth and Planetary Science Letters, vol. 265, no. 1-2, pp. 96-111, DOI: 10.1016/j.epsl.2007.09.038.

Korsch, RJ, Huston, DL, Henderson, RA, Blewett, RS, Withnall, IW, Fergusson, CL, Collins, WJ, Saygin, E, Kositcin, N, Meixner, AJ, Chopping, R, Henson, PA, Champion, DC, Hutton, LJ, Wormald, R, Holzschuh, J \& Costelloe, RD 2012, 'Crustal architecture and geodynamics of North Queensland, Australia: Insights from deep seismic reflection profiling', Tectonophysics, vol. 572-573, pp. 76-99, DOI: 10.1016/j.tecto.2012.02.022.

Korsch, RJ \& Kositcin, N 2010, South Australian Seismic and MT Workshop 2010, Record, no. 2010/10, Geoscience Australia, Canberra, Australian Capital Territory.

Kromkhun, K, Foden, JD, Hore, SB \& Baines, G 2013, 'Geochronology and Hf isotopes of the bimodal mafic-felsic high heat producing igneous suite from Mt Painter Province, South Australia', Gondwana Research, vol. 24, no. 3-4, 2013/11/01/, pp. 1067-1079, DOI: 10.1016/j.gr.2013.01.011.

Li, Z-X, Bogdanova, SV, Collins, AS, Davidson, A, De Waele, B, Ernst, RE, Fitzsimons, ICW, Fuck, RA, Gladkochub, DP, Jacobs, J, Karlstrom, KE, Lu, S, Natapov, LM, Pease, V, Pisarevsky, SA, Thrane, K \& Vernikovsky, V 2008, 'Assembly, configuration, and break-up history of Rodinia: A synthesis', Precambrian Research, vol. 160, no. 1-2, Jan 5, pp. 179-210, DOI: 10.1016/j.precamres.2007.04.021.

Li, Z-X \& Powell, CM 2001, 'An outline of the palaeogeographic evolution of the Australasian region since the beginning of the Neoproterozoic', Earth-Science Reviews, vol. 53, no. 3, 2001/04/01/, pp. 237-277, DOI: 10.1016/S0012-8252(00)00021-0.

Li, Z-X, Zhang, L \& Powell, CM 1995, 'South China in Rodinia: Part of the missing link between Australia-East Antarctica and Laurentia?', Geology, vol. 23, no. 5, pp. 407-410, DOI: 10.1130/0091-7613(1995)023<0407:SCIRPO>2.3.CO;2.

Lloyd, JC, Blades, ML, Counts, JW, Collins, AS, Amos, KJ, Wade, BP, Hall, JW, Hore, S, Ball, AL, Shahin, S \& Drabsch, M 2020, 'Neoproterozoic geochronology and provenance of the Adelaide Superbasin', Precambrian Research, vol. 350, 2020/07/08/, p. 105849, DOI: 10.1016/j.precamres.2020.105849.

Ludwig, KR 1998, 'On the Treatment of Concordant Uranium-Lead Ages', Geochimica et Cosmochimica Acta, vol. 62, no. 4, 1998/02/01/, pp. 665-676, DOI: 10.1016/S00167037(98)00059-3.

Mackay, WG 2011, 'Structure and sedimentology of the Curdimurka Subgroup, northern Adelaide Fold Belt, South Australia', Doctoral Thesis thesis, Doctor of Philosophy thesis, University of Tasmania, Hobart, Tasmania, viewed 4/09/2018, <https://eprints.utas.edu.au/12486/>.

Maidment, DW, Williams, IS \& Hand, M 2007, 'Testing long-term patterns of basin sedimentation by detrital zircon geochronology, Centralian Superbasin, Australia', Basin Research, vol. 19, no. 3, 2007/09/01, pp. 335-360, DOI: 10.1111/j.1365-2117.2007.00326.x.

Matenco, LC \& Haq, BU 2020, 'Multi-scale depositional successions in tectonic settings', EarthScience Reviews, vol. 200, DOI: 10.1016/j.earscirev.2019.102991.

Mawson, D 1949, 'Sturtian tillite of Mount Jacob and Mount Warren Hastings, north Flinders Ranges', Transactions of the Royal Society of South Australia, vol. 72, pp. 244-251.

McAvaney, S 2012, 'The Cooyerdoo Granite: Paleo- and Mesoarchean basement of the Gawler Craton', MESA Journal, vol. 65, pp. 31-40, https://sarigbasis.pir.sa.gov.au/WebtopEw/ws/samref/sarig1/wci/Record?r=0\&m=1\&w=catn $\underline{0=2035289}$.

McKenzie, DP, Davies, D \& Molnar, P 1970, 'Plate Tectonics of the Red Sea and East Africa', Nature, vol. 226, no. 5242, 1970/04/01, pp. 243-248, DOI: 10.1038/226243a0.

Meaney, KJ 2017, 'Proterozoic crustal growth in the southeastern Gawler Craton: the development of the Barossa Complex, and an assessment of the detrital zircon method', Department of Geology and Geophysics, Doctoral Thesis thesis, Doctor of Philosophy thesis, University of Adelaide, Adelaide, South Australia, <http://hdl.handle.net/2440/114255>. 
Merdith, AS, Collins, AS, Williams, SE, Pisarevsky, SA, Foden, JD, Archibald, DB, Blades, ML, Alessio, BL, Armistead, SE, Plavsa, D, Clark, C \& Müller, RD 2017a, 'A full-plate global reconstruction of the Neoproterozoic', Gondwana Research, vol. 50, 2017/10/01/, pp. 84-134, DOI: 10.1016/j.gr.2017.04.001.

Merdith, AS, Williams, SE, Collins, AS, Tetley, MG, Mulder, JA, Blades, ML, Young, A, Armistead, SE, Cannon, J, Zahirovic, S \& Müller, RD 2021, 'Extending full-plate tectonic models into deep time: Linking the Neoproterozoic and the Phanerozoic', Earth-Science Reviews, vol. 214, DOI: 10.1016/j.earscirev.2020.103477.

Merdith, AS, Williams, SE, Müller, RD \& Collins, AS 2017b, 'Kinematic constraints on the Rodinia to Gondwana transition', Precambrian Research, vol. 299, 2017/09/01/, pp. 132-150, DOI: 10.1016/j.precamres.2017.07.013.

Mills, BJW, Krause, AJ, Scotese, CR, Hill, DJ, Shields, GA \& Lenton, TM 2019, 'Modelling the long-term carbon cycle, atmospheric $\mathrm{CO} 2$, and Earth surface temperature from late Neoproterozoic to present day', Gondwana Research, vol. 67, pp. 172-186, DOI: 10.1016/j.gr.2018.12.001.

Moores, EM 1991, 'Southwest U.S.-East Antarctic (SWEAT) connection: A hypothesis', Geology, vol. 19, no. 5, pp. 425-428, DOI: 10.1130/0091-7613(1991)019<0425:SUSEAS>2.3.C0;2.

Morrissey, LJ, Barovich, KM, Hand, M, Howard, KE \& Payne, JL 2019, 'Magmatism and metamorphism at ca. $1.45 \mathrm{Ga}$ in the northern Gawler Craton: The Australian record of rifting within Nuna (Columbia)', Geoscience Frontiers, vol. 10, no. 1, 2019/01/01/, pp. 175-194, DOI: 10.1016/j.gsf.2018.07.006.

Morrissey, LJ, Hand, M, Wade, BP \& Szpunar, MA 2013, 'Early Mesoproterozoic metamorphism in the Barossa Complex, South Australia: links with the eastern margin of Proterozoic Australia', Australian Journal of Earth Sciences, vol. 60, no. 8, pp. 769-795, DOI: 10.1080/08120099.2013.860623.

Mulder, JA, Berry, RF, Halpin, JA, Meffre, S \& Everard, JL 2018, 'Depositional age and correlation of the Oonah Formation: refining the timing of Neoproterozoic basin formation in Tasmania', Australian Journal of Earth Sciences, vol. 65, no. 3, 2018/04/03, pp. 391-407, DOI: 10.1080/08120099.2018.1426629.

Munson, TJ, Kruse, PD \& Ahmad, M 2013, 'Chapter 22: Centralian Superbasin', in M Ahmad \& TJ Munson (eds), Geology and mineral resources of the Northern Territory, Northern Territory Geological Survey, Northern Territory.

Nordsvan, AR, Collins, WJ, Li, Z-X, Spencer, CJ, Pourteau, A, Withnall, IW, Betts, PG \& Volante, S 2018, 'Laurentian crust in northeast Australia: Implications for the assembly of the supercontinent Nuna', Geology, vol. 46, no. 3, pp. 251-254, DOI: 10.1130/g39980.1.

Normington, VJ \& Donnellan, NC 2020, Characterisation of the Neoproterozoic succession of the northeastern Amadeus Basin, Northern Territory, Record, no. 2020-010, Northern Territory Geological Survey, <https://geoscience.nt.gov.au/gemis/ntgsjspui/handle/1/90622>.

Normington, VJ \& Edgoose, CJ 2018, 'Neoproterozoic stratigraphic revisions to key drillholes in the Amadeus Basin - implications for basin palaeogeography and petroleum and minerals potential', in AGES 2018, Northern Territory Geological Survey, Alice Springs.

Norris, A \& Danyushevsky, L 2018, 'Towards Estimating the Complete Uncertainty Budget of Quantified Results Measured by LA-ICP-MS', paper presented at Goldschmidt, Boston.

O'Neill, HSC 2016, 'The Smoothness and Shapes of Chondrite-normalized Rare Earth Element Patterns in Basalts', Journal of Petrology, vol. 57, no. 8, pp. 1463-1508, DOI: 10.1093/petrology/egw047.

Page, RW, Conor, CHH, Stevens, BPJ, Gibson, GM, Preiss, WV \& Southgate, PN 2005, 'Correlation of Olary and Broken Hill Domains, Curnamona Province: Possible Relationship to Mount Isa and Other North Australian Pb-Zn-Ag-Bearing Successions', Economic Geology, vol. 100, no. 4, pp. 663-676, DOI: $10.2113 /$ gsecongeo.100.4.663.

Park, Y, Swanson-Hysell, NL, Xian, H, Zhang, S, Condon, DJ, Fu, H \& Macdonald, FA 2021, 'A Consistently High-Latitude South China From 820 to 780 Ma: Implications for Exclusion From Rodinia and the Feasibility of Large-Scale True Polar Wander', Journal of Geophysical Research: Solid Earth, vol. 126, no. 6, DOI: 10.1029/2020jb021541. 
Paul, E, Flöttmann, T \& Sandiford, M 1999, 'Structural geometry and controls on basement-involved deformation in the northern Flinders Ranges, Adelaide Fold Belt, South Australia', Australian Journal of Earth Sciences, vol. 46, no. 3, pp. 343-354, DOI: 10.1046/j.14400952.1999.00711.x.

Payne, JL, Barovich, KM \& Hand, M 2006, 'Provenance of metasedimentary rocks in the northern Gawler Craton, Australia: Implications for Palaeoproterozoic reconstructions', Precambrian Research, vol. 148, no. 3, 2006/08/10/, pp. 275-291, DOI: 10.1016/j.precamres.2006.05.002.

Payne, JL, Ferris, G, Barovich, KM \& Hand, M 2010, 'Pitfalls of classifying ancient magmatic suites with tectonic discrimination diagrams: An example from the Paleoproterozoic Tunkillia Suite, southern Australia', Precambrian Research, vol. 177, no. 3-4, pp. 227-240, DOI: 10.1016/j.precamres.2009.12.005.

Powell, CM 1998, 'Assembly and Break-up of Rodinia Leading to Formation of Gondwana Land', in RT Bird (ed.), The Assembly and Breakup of Rodinia, Geological Society of Australia, Sydney, New South Wales, pp. 49-53.

Preiss, WV 1974, 'The River Broughton Beds - a Willouran sequence in the Spalding inlier', Quarterly Geological Notes, vol. 49, pp. 2-8.

Preiss, WV 1985, Stratigraphy and Tectonics of the Worumba Anticline and Associated Intrusive Breccias, Bulletin, 52, Geological Survey of South Australia, South Australia.

Preiss, WV 1987, Adelaide Geosyncline-late Proterozoic stratigraphy, sedimentation, palaeontology and tectonics, Bulletin, 53, Geological Survey of South Australia, Adelaide, South Australia.

Preiss, WV 1993, 'Neoproterozoic', in JF Drexel, WV Preiss \& AJ Parker (eds), The geology of South Australia, vol. 1 The Precambrian, Geological Survey of South Australia, South Australia, pp. 171-204.

Preiss, WV 2000, 'The Adelaide Geosyncline of South Australia and its significance in Neoproterozoic continental reconstruction', Precambrian Research, vol. 100, no. 1-3, Mar, pp. 21-63, DOI: 10.1016/S0301-9268(99)00068-6.

Preiss, WV, Alexander, EM, Cowley, WM \& Schwarz, MP 2002, 'Towards defining South Australia's geological provinces and sedimentary basins', MESA Journal, vol. 27, pp. 39-52, https://sarigbasis.pir.sa.gov.au/WebtopEw/ws/samref/sarig1/wci/Record? r=0\&m=1\&w=catn $\underline{0=2022981 .}$.

Preiss, WV, Drexel, JF \& Reid, AJ 2009, 'Definition and age of the Kooringa Member of the Skillogalee Dolomite: host for Neoproterozoic (c. $790 \mathrm{Ma}$ ) porphyry related copper mineralisation at Burra', MESA Journal, vol. 55, pp. 19-33, https://sarigbasis.pir.sa.gov.au/WebtopEw/ws/samref/sarig1/wci/Record?r=0\&m=1\&w=catn $\underline{0}=2028895$.

Pupin, JP 1980, 'Zircon and granite petrology', Contributions to Mineralogy and Petrology, vol. 73, no. 3, 1980/08/01, pp. 207-220, DOI: 10.1007/BF00381441.

Purcell, PG 2018, 'Re-imagining and re-imaging the development of the East African Rift', Petroleum Geoscience, vol. 24, no. 1, pp. 21-40, DOI: 10.1144/petgeo2017-036.

Reid, AJ, Jagodzinski, EA, Fraser, GL \& Pawley, MJ 2014, 'SHRIMP U-Pb zircon age constraints on the tectonics of the Neoarchean to early Paleoproterozoic transition within the Mulgathing Complex, Gawler Craton, South Australia', Precambrian Research, vol. 250, 2014/09/01/, pp. 27-49, DOI: 10.1016/j.precamres.2014.05.013.

Reid, AJ \& Payne, JL 2017, 'Magmatic zircon Lu-Hf isotopic record of juvenile addition and crustal reworking in the Gawler Craton, Australia', Lithos, vol. 292-293, 2017/11/01/, pp. 294-306, DOI: $10.1016 /$ j.lithos.2017.08.010.

Rubatto, D 2002, 'Zircon trace element geochemistry: partitioning with garnet and the link between U-Pb ages and metamorphism', Chemical Geology, vol. 184, no. 1, 2002/03/15/, pp. 123138, DOI: 10.1016/S0009-2541(01)00355-2.

Rutherford, L, Hand, M \& Barovich, K 2007, 'Timing of Proterozoic metamorphism in the southern Curnamona Province: implications for tectonic models and continental reconstructions *', Australian Journal of Earth Sciences, vol. 54, no. 1, pp. 65-81, DOI: 10.1080/08120090600981459. 
Shannon, RD 1976, 'Revised effective ionic radii and systematic studies of interatomic distances in halides and chalcogenides', Acta Crystallographica Section A, vol. 32, no. 5, 1976/09/01, pp. 751-767, DOI: 10.1107/S0567739476001551.

Shields, GA, Strachan, RA, Porter, SM, Halverson, GP, Macdonald, FA, Plumb, KA, de Alvarenga, CJ, Banerjee, DM, Bekker, A, Bleeker, W, Brasier, A, Chakraborty, PP, Collins, AS, Condie, K, Das, K, Evans, DAD, Ernst, R, Fallick, AE, Frimmel, H, Fuck, R, Hoffman, PF, Kamber, BS, Kuznetsov, AB, Mitchell, RN, Poiré, DG, Poulton, SW, Riding, R, Sharma, M, Storey, C, Stueeken, E, Tostevin, R, Turner, E, Xiao, S, Zhang, S, Zhou, Y \& Zhu, M 2021, 'A template for an improved rock-based subdivision of the pre-Cryogenian timescale', Journal of the Geological Society, DOI: 10.1144 /jgs2020-222.

Slama, J \& Košler, J 2012, 'Effects of sampling and mineral separation on accuracy of detrital zircon studies', Geochemistry Geophysics Geosystems, vol. 13, no. 5, May 11, DOI: 10.1029/2012gc004106.

Sláma, J, Košler, J, Condon, DJ, Crowley, JL, Gerdes, A, Hanchar, JM, Horstwood, MSA, Morris, GA, Nasdala, L, Norberg, N, Schaltegger, U, Schoene, B, Tubrett, MN \& Whitehouse, MJ 2008, 'Plešovice zircon - A new natural reference material for $\mathrm{U}-\mathrm{Pb}$ and $\mathrm{Hf}$ isotopic microanalysis', Chemical Geology, vol. 249, no. 1, 2008/03/30/, pp. 1-35, DOI: 10.1016/j.chemgeo.2007.11.005.

Smithies, RH, Howard, HM, Evins, PM, Kirkland, CL, Bodorkos, S \& Wingate, MTD 2008, The west Musgrave Complex - new geological insights from recent mapping, geochronology, and geochemical studies, Record, no. 2008/19, Geological Survey of Western Australia, <http://dmpbookshop.eruditetechnologies.com.au/product/the-west-musgrave-complexnew-geological-insights-from-recent-mapping-geochronology-and-geochemicalstudies.do>.

Smithies, RH, Howard, HM, Evins, PM, Kirkland, CL, Kelsey, DE, Hand, M, Wingate, MTD, Collins, AS \& Belousova, EA 2011, 'High-Temperature Granite Magmatism, Crust-Mantle Interaction and the Mesoproterozoic Intracontinental Evolution of the Musgrave Province, Central Australia', Journal of Petrology, vol. 52, no. 5, pp. 931-958, DOI: 10.1093/petrology/egr010.

Smits, RG, Collins, WJ, Hand, M, Dutch, R \& Payne, J 2014, 'A Proterozoic Wilson cycle identified by $\mathrm{Hf}$ isotopes in central Australia: Implications for the assembly of Proterozoic Australia and Rodinia', Geology, vol. 42, no. 3, pp. 231-234, DOI: 10.1130/g35112.1.

Sprigg, RC 1952, 'Sedimentation in the Adelaide Geosyncline and the formation of the continental terrace', in MF Glaessner \& RC Sprigg (eds), Sir Douglas Mawson Anniversary Volume, The University of Adelaide, South Australia, pp. 153-159.

Stein, S, Stein, CA, Elling, R, Kley, J, Keller, GR, Wysession, M, Rooney, T, Frederiksen, A \& Moucha, R 2018, 'Insights from North America's failed Midcontinent Rift into the evolution of continental rifts and passive continental margins', Tectonophysics, vol. 744, pp. 403-421, DOI: $10.1016 /$ j.tecto.2018.07.021.

Stüeken, EE, Buick, R \& Lyons, TW 2019, 'Revisiting the depositional environment of the Neoproterozoic Callanna Group, South Australia', Precambrian Research, vol. 334, 2019/11/01/, p. 105474, DOI: 10.1016/j.precamres.2019.105474.

Tesfaye, S, Harding, DJ \& Kusky, TM 2003, 'Early continental breakup boundary and migration of the Afar triple junction, Ethiopia', GSA Bulletin, vol. 115, no. 9, pp. 1053-1067, DOI: 10.1130/B25149.1.

Thomson, BP 1966, 'The lower boundary of the Adelaide system and older basement relationships in south Australia', Journal of the Geological Society of Australia, vol. 13, no. 1, 1966/01/01, pp. 203-228, DOI: 10.1080/00167616608728610.

Tiddy, CJ \& Giles, D 2020, 'Suprasubduction zone model for metal endowment at 1.60-1.57 Ga in eastern Australia', Ore Geology Reviews, vol. 122, DOI: 10.1016/j.oregeorev.2020.103483.

Tostevin, R \& Mills, BJW 2020, 'Reconciling proxy records and models of Earth's oxygenation during the Neoproterozoic and Palaeozoic', Interface Focus, vol. 10, no. 4, Aug 6, p. 20190137, DOI: $10.1098 /$ rsfs. 2019.0137. 
Travers, DC 2015, 'Geochronology, geochemistry and petrogenesis of mafic magmatism in the Coompana Province', Department of Earth Sciences, thesis thesis, Bachelor of Science (Honours) thesis, University of Adelaide, Adelaide, South Australia, $<$ http://hdl.handle.net/2440/118238>.

Varet, J 2018, Geology of Afar (East Africa), Regional Geology Reviews, 1 edn, Springer, Cham.

Verdel, C, Campbell, MJ \& Allen, CM 2021, 'Detrital zircon petrochronology of central Australia, and implications for the secular record of zircon trace element composition', Geosphere, DOI: 10.1130/ges02300.1.

Vermeesch, P 2018, 'IsoplotR: a free and open toolbox for geochronology', Geoscience Frontiers, vol. 9, no. 5, 2018/04/11/, DOI: 10.1016/j.gsf.2018.04.001.

Vermeesch, P 2021, 'On the treatment of discordant detrital zircon U-Pb data', Geochronology, vol. 3, no. 1, pp. 247-257, DOI: 10.5194/gchron-3-247-2021.

Vermeesch, P, Resentini, A \& Garzanti, E 2016, 'An R package for statistical provenance analysis', Sedimentary Geology, vol. 336, 2016/05/01/, pp. 14-25, DOI: 10.1016/j.sedgeo.2016.01.009.

Volante, S, Pourteau, A, Collins, WJ, Blereau, E, Li, ZX, Smit, M, Evans, NJ, Nordsvan, AR, Spencer, CJ, McDonald, BJ, Li, J \& Günter, C 2020, 'Multiple P-T-d-t paths reveal the evolution of the final Nuna assembly in northeast Australia', Journal of Metamorphic Geology, vol. 38, no. 6, pp. 593-627, DOI: 10.1111/jmg.12532.

von der Borch, CC 1980, 'Evolution of late proterozoic to early paleozoic Adelaide foldbelt, Australia: Comparisons with postpermian rifts and passive margins', Tectonophysics, vol. 70, no. 1, 1980/12/01/, pp. 115-134, DOI: 10.1016/0040-1951(80)90023-2.

Wade, BP, Kelsey, DE, Hand, M \& Barovich, KM 2008, 'The Musgrave Province: Stitching north, west and south Australia', Precambrian Research, vol. 166, no. 1, 2008/10/30/, pp. 370-386, DOI: 10.1016/j.precamres.2007.05.007.

Wade, CE 2011, 'Definition of the Mesoproterozoic Ninnerie Supersuite, Curnamona Province, South Australia', MESA Journal, vol. 62, September 2011, pp. 25-42.

Wade, CE, McAvaney, SO \& Gordan, GA 2014, 'The Beda Basalt: new geochemistry, isotopic data and its definition', MESA Journal, vol. 73, no. 2, 2014, pp. 24-39.

Wade, CE, Reid, AJ, Wingate, MTD, Jagodzinski, EA \& Barovich, K 2012, 'Geochemistry and geochronology of the c. 1585Ma Benagerie Volcanic Suite, southern Australia: Relationship to the Gawler Range Volcanics and implications for the petrogenesis of a Mesoproterozoic silicic large igneous province', Precambrian Research, vol. 206-207, pp. 17-35, DOI: 10.1016/j.precamres.2012.02.020.

Walter, MR, Veevers, JJ, Calver, CR \& Grey, K 1995, 'Neoproterozoic stratigraphy of the Centralian Superbasin, Australia', Precambrian Research, vol. 73, no. 1, 1995/05/01/, pp. 173-195, DOI: 10.1016/0301-9268(94)00077-5.

Wang, P, Zhao, G, Liu, Q, Han, Y, Yao, J \& Li, J 2020, 'Zircons from the Tarim basement provide insights into its positions in Columbia and Rodinia supercontinents', Precambrian Research, vol. 341, 2020/06/01/, p. 105621, DOI: 10.1016/j.precamres.2020.105621.

Wang, X-C, Li, X-H, Li, Z-X, Liu, Y \& Yang, Y-H 2010, 'The Willouran basic province of South Australia: Its relation to the Guibei large igneous province in South China and the breakup of Rodinia', Lithos, vol. 119, no. 3, 2010/10/01/, pp. 569-584, DOI: 10.1016/j.lithos.2010.08.011.

Wen, B, Evans, DAD \& Li, Y-X 2017, 'Neoproterozoic paleogeography of the Tarim Block: An extended or alternative "missing-link" model for Rodinia?', Earth and Planetary Science Letters, vol. 458, 2017/01/15/, pp. 92-106, DOI: 10.1016/j.epsl.2016.10.030.

Wen, B, Evans, DAD, Wang, C, Li, Y-X \& Jing, X 2018, 'A positive test for the Greater Tarim Block at the heart of Rodinia: Mega-dextral suturing of supercontinent assembly', Geology, vol. 46, no. 8, pp. 687-690, DOI: 10.1130/G40254.1.

Werner, M, Dutch, RA, Pawley, MJ \& Krapf, CBE 2018, 'Amata Dolerite, Musgrave Province: Connections to Neoproterozoic mantle plume magmatism within Rodinia', MESA Journal, vol. 87, no. 2, pp. 34-45. 
Wiedenbeck, M, Allé, P, Corfu, F, Griffin, WL, Meier, M, Oberli, F, Quadt, AV, Roddick, JC \& Spiegel, W 1995, 'Three Natural Zircon Standards for U-Th-Pb, Lu-Hf, Trace Element and REE Analyses', Geostandards Newsletter, vol. 19, no. 1, 1995/04/01, pp. 1-23, DOI: 10.1111/j.1751908X.1995.tb00147.x.

Wiedenbeck, M, Hanchar, JM, Peck, WH, Sylvester, P, Valley, J, Whitehouse, M, Kronz, A, Morishita, Y, Nasdala, L, Fiebig, J, Franchi, I, Girard, JP, Greenwood, RC, Hinton, R, Kita, N, Mason, PRD, Norman, M, Ogasawara, M, Piccoli, PM, Rhede, D, Satoh, H, Schulz-Dobrick, B, Skår, O, Spicuzza, MJ, Terada, K, Tindle, A, Togashi, S, Vennemann, T, Xie, Q \& Zheng, YF 2004, 'Further Characterisation of the 91500 Zircon Crystal', Geostandards and Geoanalytical Research, vol. 28, no. 1, 2004/05/01, pp. 9-39, DOI: 10.1111/j.1751-908X.2004.tb01041.x. Williams, FM 2016, Understanding Ethiopia: Geology and Scenery, GeoGuide, 1 edn, Springer, Cham. Williams, MA \& Reid, AJ 2021, 'Linking lithostratigraphy to mineral potential for the Archean to earliest Paleoproterozoic Mulgathing Complex, central Gawler Craton', MESA Journal, vol. 94, pp. 4-18.

Wingate, MTD, Campbell, IH, Compston, W \& Gibson, GM 1998, 'Ion microprobe U-Pb ages for Neoproterozoic basaltic magmatism in south-central Australia and implications for the breakup of Rodinia', Precambrian Research, vol. 87, no. 3, 1998/02/01/, pp. 135-159, DOI: 10.1016/S0301-9268(97)00072-7.

Wingate, MTD, Pisarevsky, SA \& Evans, DAD 2002, 'Rodinia connections between Australia and Laurentia: no SWEAT, no AUSWUS?', Terra Nova, vol. 14, no. 2, 2002/04/01, pp. 121-128, DOI: 10.1046/j.1365-3121.2002.00401.x.

Wu, G, Yang, S, Liu, W, Nance, RD, Chen, X, Wang, Z \& Xiao, Y 2021, 'Switching from advancing to retreating subduction in the Neoproterozoic Tarim Craton, NW China: Implications for Rodinia breakup', Geoscience Frontiers, vol. 12, no. 1, pp. 161-171, DOI: 10.1016/j.gsf.2020.03.013.

Wysoczanski, RJ \& Allibone, AH 2004, 'Age, Correlation, and Provenance of the Neoproterozoic Skelton Group, Antarctica: Grenville Age Detritus on the Margin of East Antarctica', Journal of Geology, vol. 112, no. 4, pp. 401-416, DOI: 10.1086/421071.

Zhao, J-x, McCulloch, MT \& Korsch, RJ 1994, 'Characterisation of a plume-related $~ 800 \mathrm{Ma}$ magmatic event and its implications for basin formation in central-southern Australia', Earth and Planetary Science Letters, vol. 121, no. 3, 1994/02/01/, pp. 349-367, DOI: 10.1016/0012-821X(94)90077-9.

Zwaan, F, Corti, G, Keir, D \& Sani, F 2020, 'A review of tectonic models for the rifted margin of Afar: Implications for continental break-up and passive margin formation', Journal of African Earth Sciences, vol. 164, DOI: 10.1016/j.jafrearsci.2019.103649. 


\section{Appendix - Use of NIST610 as primary 207Pb/206Pb standard}

1136 Matrix matched reference materials are essential for the accurate determination of $\mathrm{U} / \mathrm{Pb}$ ratios, and 1137 thus calculated ages, of accessory minerals such as zircon via laser ablation mass spectrometry 1138 (Allen \& Campbell 2012; Kuhn et al. 2010; Miliszkiewicz et al. 2015; Thompson et al. 2018). This is 1139 due to the offset in ratio and subsequently age determinations caused by "matrix effects" (Košler et 1140 al. 2005; Marillo-Sialer et al. 2014; Schaltegger et al. 2015). Primarily, this is a result of downhole 1141 fractionation (Paton et al. 2010; Ver Hoeve et al. 2018) with one of the major causes being laser 1142 induced elemental fractionation (LIEF) of U from Pb in the crystal lattice (Košler et al. 2005; Marillo1143 Sialer et al. 2014). However, it has been determined that there is negligible to no fractionation of $\mathrm{Pb}$ 1144 isotopes during laser ablation of various accessory minerals and silicate glasses (Allen \& Campbell 1145 2012; Guillong et al. 2020; Miliszkiewicz et al. 2015; Souders \& Sylvester 2010), thus allowing the 1146 use of non-matrix matched silicate glasses (e.g., NIST610) as external reference materials for the 1147 determination of accurate Pb isotope ratios. Methodology using NIST610, or other silicate glasses, as 1148 the 207Pb/206 Pb primary reference material has been successfully used in past (Guillong et al. 1149 2020; Halpin et al. 2014; Large et al. 2013; Standish et al. 2013). We further validate this as the 1150 NIST610 corrected 207Pb/206Pb ratio and calculated age for every natural zircon reference material 1151 analysed is within uncertainty at high accuracy [Figure A1] of their CA-ID-TIMS determined values 1152 (Horstwood et al. 2016). The use of NIST610 allows for more precise determination of Pb isotope 1153 ratios due to the better homogeneity and characterisation of the reference material (Jochum et al. 1154 2011) while retaining accuracy. This is useful in overcoming the higher degrees of uncertainty 1155 associated with natural reference materials that are measurably heterogenous (Horstwood et al. 1156 2016; Schaltegger et al. 2021), which is likely the result of radiation damage induced lead loss, 1157 zonation in zircon crystallinity, or protracted growth. 


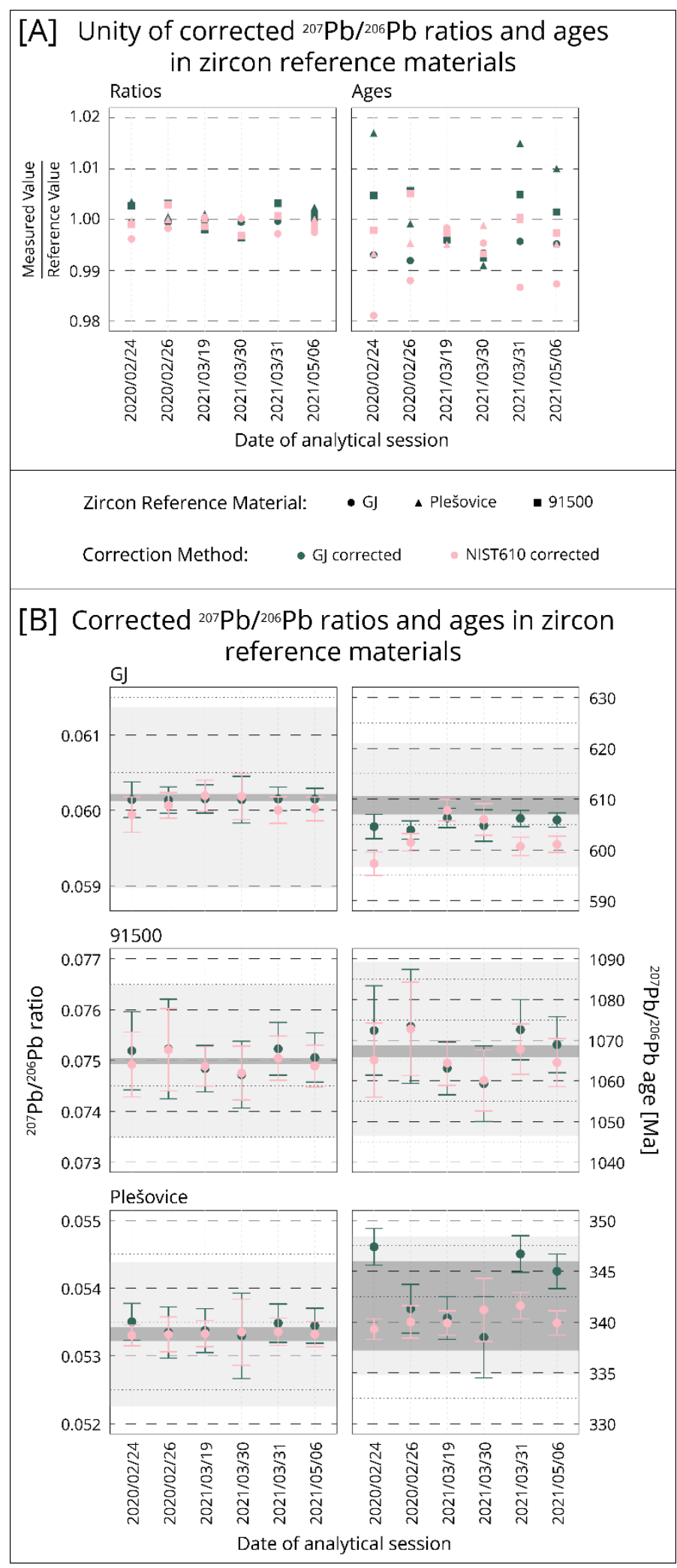

Figure A1-A: Unity measure (observed/reference value) of corrected $\mathrm{Pb}$ isotope ratios and ages. $\mathbf{B}$ : individual observed corrected ratios and ages for each natural zircon reference material used. Dark grey shading is the reference value range $(2 x$ standard error), light grey shading is the $2 \%$ unity range (reference value $\pm 2 \%$ ). Uncertainties on observations are 2 standard error. Refence values are from (Horstwood et al. 2016) 